\title{
Geophysical constraints on the lithospheric structure in the northeastern South China Sea and its implications for the South China Sea geodynamics
}

\author{
Liu Siqing ${ }^{1,6}$, Zhao Minghui ${ }^{1,{ }^{*}}$, Sibuet Jean-Claude ${ }^{1,2}$, Qiu Xuelin ${ }^{1,6}$, Wu Jonny ${ }^{3}$, Zhang Jiazheng ${ }^{1}$, \\ Chen Chuanxu ${ }^{4}, \mathrm{Xu} \mathrm{Ya}^{5}$, Sun Longtao ${ }^{1}$
}

${ }^{1}$ Key Laboratory of Ocean and Marginal Sea Geology, South China Sea Institute of Oceanology, Chinese Academy of Sciences, Guangzhou 510301, China

${ }^{2}$ Ifremer Centre de Brest, 29280 Plouzané, France and 44 rue du Cloitre, 29280 Plouzané, France

${ }^{3}$ University of Houston, Department of Earth and Atmospheric Sciences, Science \& Research Building 1, 3507 Cullen Boulevard, Houston, TX 77204, USA

${ }^{4}$ Institute of Deep-sea Science and Engineering, Chinese Academy of Sciences, Sanya 572000, China

${ }^{5}$ Institute of Geology and Geophysics, Chinese Academy of Sciences, Beijing 100029, China

${ }^{6}$ University of Chinese Academy of Sciences, Beijing 100049, China

* Corresponding author: Minghui Zhao, email address : $\underline{\text { mhzhao@scsio.ac.cn }}$

\begin{abstract}
:
An E-W oriented OBS2015-2 wide-angle refraction profile was shot in the northeastern South China Sea (SCS) between refraction profiles T1 and T2 in order to better understand the variability of the crustal composition and the role of specific tectonic features. P-wave velocity models established from forward and inversion modeling imaged a 12 to $15 \mathrm{~km}$-thick thinned continental crust and a high velocity layer (HVL) in the lower crust which is interpreted as magmatic underplating. Profile OBS2015-2 cut across the Taiwan transfer zone (TTZ), which separates two consecutive rifted segments of different orientations in the northeastern SCS. The TTZ is a well-defined upper crustal feature characterized by a HVL with different thickness on both sides. We have defined the southward limit of the thinned continental domain with the typical oceanic domain as a continent-ocean boundary (COB). The COB between the drilling area of IODP legs 367-368 to the Manila trench is characterized by a sharp contrast between the low amplitude, irregular shape magnetic anomalies and the high amplitude, elongated shape magnetic anomalies, which are associated with the thinned continental domain and the oceanic domain, respectively. We further extend the COB into the 400 to $500 \mathrm{~km}$ wide unfolded Manila slab located east of the Manila trench by using mid-slab $d V p$ tomographic velocities to define the boundary between subducted oceanic and thinned continental crust. The location of the reconstructed northeast SCS COB appears to step northwards toward Taiwan across a $400 \mathrm{~km} \mathrm{~N}-\mathrm{S}$ segment, providing new constraints on SCS geodynamics at the end of spreading and its later tectonic evolution.
\end{abstract}




\section{Highlights}

- Thinned continental crust intruded by post-rifting volcanics in northeastern SCS $>$ The TTZ transfer zone separates two consecutive rifted continental segments. COB can be distinguished from $d V p$ variations within the unfolded Manila slab. Two plates kinematic arrangement at the end of SCS seafloor spreading

Keywords: Northeastern South China Sea, Continent-ocean boundary (COB), Wide-angle reflection/refraction data, Thinned continental crust intruded by post-rifting volcanism, Taiwan transfer zone (TTZ) 


\section{Introduction}

The South China Sea (SCS), one of largest marginal seas in the Western Pacific, has experienced a near-complete Wilson cycle with continental rifting, breakup, and seafloor spreading, followed by partial subduction along the Manila trench. In the last decade, geophysical surveys have been focused on the deep lithospheric structure of the northeastern SCS near the Manila subduction zone. In particular, the continent-ocean transitional zone and relevant geodynamic processes has 
been an important scientific topic. In this work, the SCS continent-ocean boundary (COB) is defined as the landward limit of the typical oceanic crust, and the domain between the COB and the typical thinned continental crust is referred to as the continent-ocean transition (COT). The COT might consist of exhumed mantle as for the Galicia margin (Davy et al., 2016), exhumed lower crust as for the Angola margin (Sibuet and Tucholke, 2012), rafts of continental crust over abnormally thick oceanic crust, or crust of unknown nature. The interpretation of multi-channel seismic (MCS) profiles in the area of IODP Legs 367-368 shows that the COT is very narrow (maximum 10-20 km wide) (Jian et al., 2018; Sun et al., 2018) or extremely narrow (a few km wide) (Cameselle et al., 2015), or even not existent (Taylor, 2017). The crustal nature of the COT is also controversial (Sun et al., 2016). Unfortunately, the controversies on width and crust nature of the COT were not resolved by drilling (e. g., Sun et al., 2018; Jian et al., 2018; Zhao et al., 2017; 2018a). Present-day ongoing discussions suggest that a COT might not actually exist within the northern SCS, as MCS profiles in the northeastern SCS do not show the presence of a COT. Therefore, we will use the notion of COB rather than COT, although it is possible that a COT with highly reduced width may exist. In the past, different $\mathrm{COB}$ locations were proposed (Fig. 1): 1) COB1 was based on the identification of magnetic lineations associated with typical oceanic crust (Taylor and Hayes, 1983; Briais et al., 1993; Barckhausen et al., 2014; Li et al., 2014). 2) COB2 was defined by Hsu et al. (2004), who mapped new E-W trending magnetic lineations in the northeasternmost SCS and interpreted them as seafloor spreading magnetic anomalies C15 to C17 dated 35 and 37.8 Ma, respectively. COB2 extends northwards of $\mathrm{C} 17$, up to $21.5^{\circ} \mathrm{N}$ and was later updated by Yeh et al. (2010) (Fig. 1). 3) McIntosh et al. (2014) updated COB1 with new constraints from refraction and MCS profiles, and considered the limits of the hyper-extended continental margin to be COB3 (Fig. 1). 4) COB4, defined in this study, 
leaves $\mathrm{C} 10$ to $\mathrm{C} 12$ magnetic lineations in the typical oceanic domain and all the NE-SW elongated volcanic ridges in the thinned continental domain. The western prolongation of COB4, located between IODP Site 1500 and IODP Site U1435 (Li et al., 2014; Jian et al., 2018; Sun et al., 2018), is established by using the magnetic anomaly map of Figure 2. The diversity of proposed SCS COBs leads to an important question that will be addressed in this study: Where is the most reasonable COB location within the northeastern SCS?

The crust located west of the Manila trench and north of the COB is thinned continental crust intruded by volcanics, rather than oceanic crust. Evidences are from the wide-angle seismic refraction lines (profiles MGL0905_20 (Lester et al., 2014), T1 and T2 (Eakin et al., 2014), MGL0905_20 (Lester et al., 2014), OBS2001 (Wang et al., 2006)) and MCS lines (Lester et al., 2013, 2014; Eakin et al., 2014; McIntosh et al., 2013, 2014; Yeh et al., 2010, 2012; Sibuet et al., 2016a). South of the continental shelf, the crust is hyper-extended and the thickness is down to $\sim 6 \mathrm{~km}$ below the continental slope, in direction of the failed rift axis (McIntosh et al., 2014) (Fig. 1). The crust becomes gradually thicker further southward over a distance of $\sim 80 \mathrm{~km}$, with tilted faulted blocks bound by normal faults. These structures are typical in highly thinned continental crust rather than oceanic crust as proposed by Hsu et al. (2004). In addition, fanning sediments on top of tilted blocks, the presence of a high amplitude reflection at the top of synrift sediments, the lack of a crustal velocity contrast as observed between oceanic crust layers 2 and 3, and possibly the existence of a HVL, are arguments in favor of highly thinned continental crust (Lester et al., 2014) rather than oceanic crust. A linear feature previously identified from swath-bathymetric, magnetic and gravity anomaly maps, and MCS profiles was interpreted as a fossil transform plate boundary, refereed to as the Luzon-Ryukyu Transform Plate Boundary (LRTPB) (Fig. 1, Sibuet et al. 2002). The new 
refraction results indicate that the LRTPB may not exist within an oceanic domain, but rather within a thinned continental crust domain. These observations lead to new questions: What are the differences in crustal nature and crustal thickness on the two sides of the LRTPB? What is the tectonic significance of this feature? Could it be considered as a transfer zone between two consecutive segments of continental margins? To answer these questions, we carried out a high-precision, crustal-scale, wide-angle seismic profile in 2015 (Profile OBS2015-2 in Fig.1), located at mid-distance between the $\mathrm{E}-\mathrm{W}$ trending $\mathrm{T} 1$ and $\mathrm{T} 2$ profiles. We then explore the geodynamic implications of our new results by incorporating our NE SCS COB constraints into Manila slab reconstructions from seismic tomography (Wu et al., 2016) to shed light on SCS geodynamics at the end of spreading and its later tectonic evolution.

\section{Seismic data acquisition and processing}

The wide-angle deep seismic profile OBS2015-2 was carried out at $\sim 21^{\circ} \mathrm{N}$ from July to August in 2015, with the R/V Shiyan 2 by the South China Sea Institute of Oceanology (Fig. 1) and the Institute of Geology and Geophysics, Chinese Academy of Sciences. The profile is located in the west of Manila trench, and has been extended further eastwards of the Manila trench in 2016. The profile shot in 2016 is not located in Figure 1 and is still under processing.

The seismic source consists of three equal-sized air-guns with a total volume of 73.74 liters $\left(4500 \mathrm{in}^{3}\right)$ towed at a depth of $10 \mathrm{~m}$ below sea surface. This kind of seismic source is large enough to carry sufficient energy, with a high firing repeatability and a high signal/noise ratio (Zhao et al., 2008), which is suitable for studying continental and oceanic crustal structures. The shooting interval time was $\sim 70-80 \mathrm{~s}$ with a ship speed of $\sim 5$ knots during the survey. 1058 shots were fired along 
Profile OBS2015-2 from west to east (Fig. 1). A single channel seismic reflection profile was simultaneously acquired. Due to its low quality, we used a single-channel record extracted from a MCS profile shot along Profile OBS2015-2 in 2016 instead (Fig. 3b). The air-gun signal was recorded by eight OBSs deployed every $15 \mathrm{~km}$ along the 190-km long seismic line (Figs. 1 and $3 \mathrm{~b}$ ). OBS2 did not record useful data and the broadband OBS located between OBS 6 and 7 was lost.

The pre-processing of OBS data included raw data transformation, correction of clock drift, shot point correction and OBS location correction, which were described in detail in Liu et al. (2017). Navigation was based on the Differential Global Positioning System. Firstly, the raw OBS data were converted into the standard SAC (seismic analysis code) format and then to the international standard format SEG-Y. Secondly, the shot point corrections were carried out including time and location corrections (Ao et al., 2010). Thirdly, the direct water-wave travel times (Pw) were picked from all seismic record sections and OBS instruments were relocated by inverting these travel times by using the Monte Carlo method (Ao et al., 2010; Zhang et al., 2013). The final processing included band-pass filtering with ramps at 3-5 and 12-14 Hz. The seismic record sections for the eight OBS stations are displayed (Figs. 4a, 5a, 6a, and S1 to S5) with a reduced crustal velocity of $6.0 \mathrm{~km} / \mathrm{s}$.

Strong energy and clear $P$-wave seismic phases are identified according to their kinematic and dynamic characteristics. PsP, Pg, PhP, Ph, PmP and Pn phases are picked to obtain the distribution of crustal velocity and interfaces (Figs. 4 to 6, and S1 to S5). Seismic phases Pw (in red) are used for relocation of the 8 OBSs. PsP, including Ps1P and Ps2P in blue and orange, are seismic phases reflected from upper and lower interfaces of the sediment layers. Seismic phases Pg (in green) are refracted from the crust. $\mathrm{PhP}$ and $\mathrm{Ph}$ (in cyan and yellow) are reflected and refracted phases from a high-velocity layer in the lower crust (HVL), respectively. The hyperbolic seismic phases PmP (in 
pink) and Pn phases (in purple red) are reflected and refracted from the Moho interface, respectively.

\section{Methodology}

\subsection{Forward ray-tracing modeling method}

The shallow geometry of the initial model is based on the interpretation of a single channel MCS profile (Fig. 2b) and regional geological and geophysical data (Zhao et al., 2010; Eakin et al., 2014; McIntosh et al., 2014). The model includes 6 layers: the sea-water layer, two sediment layers, the upper crust, the lower crust, and the upper mantle, corresponding to velocities of $1.5 \mathrm{~km} / \mathrm{s}$, 1.8-2.5 km/s and 3.0-3.5 km/s, 5.0-6.4 km/s, 6.4-6.9 km/s, and 8.0-8.2 km/s, respectively (Fig. 3c).

$P$-wave velocity modeling was first done by forward ray tracing using the RayInvr software (Zelt and Smith, 1992). Abundant travel times of PsP, Pg, PhP, Ph, PmP and Pn phases are used to obtain the distribution of crustal velocities and interfaces. Data fitting is also quantified using $\chi^{2}$ values, and the root mean square (RMS) normalized by the picking uncertainty. Typical uncertainties for best arrivals are $50 \mathrm{~ms}$. Depending on the quality of travel-times, uncertainties of $80 \mathrm{~ms}$ are assigned to Moho arrivals (Table 1).

OBS01 is located in the westernmost part of the profile at a depth of $2626 \mathrm{~m}$ (Figs. 1 and 3). In the ray-tracing records (Fig. 4), Pg seismic phases can be traced as far as $70 \mathrm{~km}$. An obvious change in time of Pg phases on the two sides of OBS01 corresponds to a significant change of basement depth shown on the associated seismic reflection profile (Fig. 4b). The $\mathrm{PhP}$ and $\mathrm{Ph}$ phases can be traced within the $60-80 \mathrm{~km}$ and $80-100 \mathrm{~km}$ offset ranges, respectively. The PmP phases are clearly seen within the -20 to $-10 \mathrm{~km}$ and 10 to $60 \mathrm{~km}$ offset ranges on both sides of OBS01. The Pn phase is observed at the offset of 55-100 km. OBS04 is located at a depth of $2704 \mathrm{~m}$ (Figs. 1 and 3). In the 
ray-tracing records (Fig. 5), Pw, Ps1P, Ps2P, Pg, PmP seismic phases are very clear. The Pg phases are within the -60 to -10 and 5 to $60 \mathrm{~km}$ offset ranges. The presence of PmP phases is the necessary condition for a good control of the Moho interface. The PmP phases are observed on both sides within the -40 to $-60 \mathrm{~km}$ and 20 to $70 \mathrm{~km}$ offset ranges of OBS04. OBS08, at a depth of $3399 \mathrm{~m}$, is located $10 \mathrm{~km}$ west of the Manila trench (Figs. 1 and 3). Pg phases are within the -60 to $8 \mathrm{~km}$ and 5 to $36 \mathrm{~km}$ offset ranges (Fig. 6). Pg phases bend down in the right side, which may be related to the bending of the subducting plate. PhP phases are clearly identified within the -95 to $-60 \mathrm{~km}$ offset range (Fig. 6). The PmP phases appear within the -40 to $-20 \mathrm{~km}$ and 20 to $40 \mathrm{~km}$ offset ranges on both sides of OBS08. The ray tracing and travel-times simulations for the other OBSs (OBS03, 04, 06, 07, and 09) are presented in the supplement (Figs. S1 to S5).

The forward modeling parameters are summarized in Table 1. The total RMS is $80 \mathrm{~ms}$, and normalized $\chi^{2}$ is 1.379 for the final velocity model, which is close to the optimal value of 1 . In general, the ray paths coverage exceeds 10 hits, reaching 50-60 hits between OBSs and over 80 hits in the upper crust (Fig. 7b), which indicates a high reliability for the final forward modeling.

\subsection{Inverted tomography modeling method}

For inversion modeling, the Tomo2D joint refraction and reflection travel-time inversion code (Korenaga et al., 2000) provides a smooth velocity model (Fig. 8). Compared to the Zelt and Smith (1992) approach, this technique requires much less a priori information and minimizes data over-interpretation. Refracted phases $(\mathrm{Pn})$ and reflections at the base of the crust $(\mathrm{PmP})$ are inverted simultaneously to provide a one-layer, continuously varying velocity model and a floating reflector representing the base of the crust. Note that the reflector at the base of the crust is not correlated with 
any velocity jump and is not the Moho interface sensu stricto. A starting velocity model is required by the tomographic approach: the sedimentary layers are built using the geometry and velocities inferred from the seismic reflection profile (Fig. 3b); for the crust, the velocity is uniformly set up at $4.5 \mathrm{~km} / \mathrm{s}$ with a vertical added gradient and $8.0 \mathrm{~km} / \mathrm{s}$ for the upper mantle. The starting floating Moho reflector is introduced at a constant depth of $11 \mathrm{~km}$. For the Tomo2d model (Fig. 8a), the grid size is $0.5 \times 0.5 \mathrm{~km}$ from the seafloor to a depth of $25 \mathrm{~km}$. The horizontal and vertical correlation lengths were set from 2 to $5 \mathrm{~km}$ and 1 to $3 \mathrm{~km}$, respectively (Table 1 ). The correlation length of the Moho reflector is $2 \mathrm{~km}$. For the initial velocity model, the RMS travel-time misfit is $367 \mathrm{~ms}$ with $\chi^{2}$ of 8.03. After 6 iterations, the RMS of the final crustal model is converging to $84 \mathrm{~ms}$ and the final $\chi^{2}$ value is reduced to 1.502 .

\subsection{Comparison of final velocity models}

The final RayInvr and Tomo2d velocity models (Figs. 7a and 8a) are consistent, except at the edge of the profile where the ray coverage is sparse. The forward model (Fig. 7a) is composed of seven layers (seawater, sediment 1 , sediment 2, upper crust, lower crust, high-velocity layer in a lower crust (HVL) and upper mantle, corresponding to velocities of $1.5 \mathrm{~km} / \mathrm{s}, 1.8-2.5 \mathrm{~km} / \mathrm{s}, 3.0-3.5$ km/s, 5.0-6.4 km/s, 6.4-6.7 km/s, 7.1-7.4 km/s, 8.0-8.2 km/s, respectively. The inversion model (Fig. 8a) yields the velocity structure with remarkable lateral velocity variations. In the two forward and inversion models (Figs. 7a and 8a), the depth of Moho is $\sim 17-20 \mathrm{~km}$ and the thickness of the crust is $\sim 12-15 \mathrm{~km}$ with a $\sim 3-4 \mathrm{~km}$ thick HVL layer $(7.1-7.4 \mathrm{~km} / \mathrm{s})$ at the base of the crust.

\subsection{Model uncertainties and resolution tests}


The ray coverage of the inversion model can be quantified with the derivative weight sum (DWS) (Fig. 8b). The ray coverage is very good in the shallow crust between OBS stations but shows significant variations with depth due to variable data quality. The uncertainties of velocities calculated by Monte Carlo analysis (Korenaga et al., 2000) are mostly less than $0.1 \mathrm{~km} / \mathrm{s}$ and the uncertainty of the Moho depth is about 0.3-0.4 km at the edge of the profile (Fig. 8c).

The checkerboard test is usually applied to evaluate the size of geological features. It is commonly used for model assessment and resolution analysis by using synthetic data. The recovery of the model is related to the distance between OBS stations. In general, the best recovery is obtained when half of the wavelength is close to the interval between adjacent OBSs. Three examples of resolved checkerboard patterns are shown for Profile OBS2015-2. The perturbed cells are $30 \times 13$ $\mathrm{km}, 20 \mathrm{~km} \times 13 \mathrm{~km}, 20 \mathrm{~km} \times 8 \mathrm{~km}$ horizontally and vertically, respectively (Fig. 9). In the tests, we first added a velocity perturbation of $\pm 5 \%$ to the grid nodes in order to construct a model that served as the input model. Synthetic arrival times are then calculated with the same source-receiver geometry. Finally the synthetic arrival times are inverted for the output model starting with the initial model, without any perturbation. By comparing the input and output models, the resolution in the model space can be determined. The recovery degree is poor in the third test (Fig. 9c). Cells with a size of $20 \mathrm{~km}$ horizontally and $13 \mathrm{~km}$ vertically are the threshold for OBS2015-2 Profile (Fig. 9b).

To test the validity of the RayInvr model, we converted the forward modeling velocities into densities (Fig. 10). In contrast with the velocity model, the density model better reflects the lateral heterogeneity in the crystalline crust and uppermost mantle (Kashubin et al., 2017). The sea-water density is $1.03 \mathrm{~g} / \mathrm{cm}^{3}$, and the density of the homogenous mantle is assumed to be $3.28 \mathrm{~g} / \mathrm{cm}^{3}$. The densities of the sedimentary layer are chosen after Hamilton (1978). For the crust, the densities are 
calculated by using an empirical law (Christensen and Mooney, 1995). In addition, the number of blocks should be reduced as much as possible to ensure the objectivity and strengthen the reliability of the model. As shown in Fig. 10, the crustal layers are split into 15 polygons with densities ranging from $2.62 \mathrm{~g} / \mathrm{cm}^{3}$ to $3.13 \mathrm{~g} / \mathrm{cm}^{3}$. The boundary effect is removed by extending the model domain outward by $50 \mathrm{~km}$ on each side of the profile (Dean et al., 2000). Observed gravity data are extracted from the global gravity data at $1 \mathrm{~min} \times 1 \mathrm{~min}$ resolution (Sandwell et al., 2013) and the Free-air gravity anomaly along the section is calculated with the MASK system (Yao et al., 2003). The density model deduced from the velocity model shows that observed and calculated values are well correlated $(\mathrm{RMS}=1.56 \mathrm{mGal})$, suggesting that the forward modeling is correct. The resulting velocity and density models bring into light the regional features of the deep structure along Profile OBS2015-2. Crustal densities below OBS01 and OBS09 located close to the Manila trench are lower than for the rest of the profile (Fig. 10). Amongst the numerous explanations, the lower densities may be associated with the thinned continental crust characterized by tilted fault blocks, and the higher densities with the presence of volcanic intrusions located at different crustal levels inside the thinned continental crust.

\section{Interpretation of refraction profiles}

\subsection{Nature of the crust along Profile 0BS2015-2}

Figures $3 b$ and $3 c$ show that the sedimentary section is $2-4 \mathrm{~km}$ thick. Fanning stratal dips indicate synrift fill between 10 and $25 \mathrm{~km}$ (Fig. 3b) and suggest the presence of two tilted fault blocks of continental crust, and these tilted blocks are better imaged along a N-S oriented profile in a N-S extension system (Taylor and Hayes, 1983; Franke et al., 2013; Zhao et al., 2016). Another 
possible tilted fault block is imaged between 85 and $100 \mathrm{~km}$. The continental origin of the tilted faults blocks is independently attested by the sedimentary nature of the upper part of the tilted blocks (e. g., Yeh et al., 2012; Lester at al., 2014). A regional unconformity characterized by a high-amplitude reflection can be followed within the post-rift sediments (Fig. 3a). Some volcanic intrusions occur where both breakup and regional unconformities are absent, for instance, the basement uplift region between 70 and $85 \mathrm{~km}$, and those at the east of $120 \mathrm{~km}$. These two possible volcanic intrusion areas are also consistent with high magnetic anomalies (Fig. 3).

The seismic velocity model of Profile OBS2015-2 provides a strong constraint on the composition of the crust. 1-D velocity-depth profiles extracted from the final RayInvr and Tomo2d velocity models below all OBSs show that velocities along the Profile OBS2015-2 structure are lower than those of the normal or atypically thick oceanic crust (Fig. 11). From $2.5 \mathrm{~km}$ below the basement to the base of the crust, which varies from 11 to $14 \mathrm{~km}$, all the OBSs curves are outside the bounds of the oceanic crust (White et al., 1992) for both RayInvr and Tomo2d models. In addition, the velocity discontinuity between layers 2 and 3 is not present in the forward velocity model. The crustal velocities are also faster than those of the extended continental crust (Christensen and Mooney, 1995). This may be due to mafic intrusions as seen in the seismic profile (Figs. 3, 7, and 8), which increase the bulk velocity.

At the base of the crust, the HVL is present along the whole profile (Figs. 7a and 8a). Similar lower-crustal velocity anomalies are also observed at the other portion along northern SCS margin (e.g., Nissen et al., 1995). The HVL (P-wave velocity of 7.0-7.5 km/s) could be either an inherited pre-rift crustal feature (Nissen et al., 1995) or a post-rift feature, which would link the HVL to magmatic underplating (e.g., Wang et al., 2006; Zhao et al., 2010; Franke, 2013). Another possible 
explanation is that the HVL may imply the sills embedding within the thinned continental lower crust resulting from volcanic intrusion during rifting (White et al., 2008). In either case, the possible explanation of the HVL and our inverted images both support that the crust below Profile OBS2015-2 is thinned continental crust intruded by igneous material, rather than typical or thick oceanic crust.

\subsection{Comparison with previously acquired refraction profiles in the northeastern SCS}

The crustal velocity model along Profile OBS2001 (Fig. 1) was the first available refraction profile in the region and was interpreted by Wang et al. (2006). The crustal thickness thins from the continental shelf (OBS11) towards the continental slope (OBS10 to OBS08). A domain named distal margin was interpreted between OBS08 and OBS02 that consisted of a 7 to $10 \mathrm{~km}$ thick upper/middle crust intruded by igneous bodies above a $4 \mathrm{~km}$ thick HVL (Wang et al., 2006; Zhao et al., 2010). Oceanic crust was interpreted south of OBS02. Note that the profile showed no evidence of a COT.

MCS Profile MGL0905_10 (Fig. 1) cut across Profile OBS2001 between OBS06 and OBS07 and also cut across elongated volcanic ridges identified as oceanic chrons C15 and C16 (Hsu et al., 2004), dated 35 and 36.3 Ma, respectively. However, McIntosh et al. (2014) demonstrated that the crust along Profile MGL0905_10 was thinned continental crust intruded by volcanics, with the presence of a 3 to $5 \mathrm{~km}$ thick HVL located at the base of the crust. In addition, the crust is intruded at chron C15 crossing by a volcanic ridge emplaced well after rifting ceased, between 24 and $17 \mathrm{Ma}$ (Sibuet et al., 2016a) as shown by uplifted sediments along the northeastern flank of the intrusion (Sibuet et al., 2016b). Thus, chron C15 identified by Hsu et al. (2004) is indicative of a post-rifting 
volcanic ridge, and not representative of oceanic crust. A clear extensional event existed between 24 and $17 \mathrm{Ma}$, with the occurrence of volcanic ridges on the northeastern SCS margin (e.g., Zhao et al., 2016) and at the location of the white star (located $20 \mathrm{~km}$ away from Profile MGL0905_10 in Fig. 1), where basaltic rocks were dredged and dated $22 \mathrm{Ma}$ by ${ }^{40} \mathrm{Ar} /{ }^{39} \mathrm{Ar}$ method (Wang et al., 2012).

The velocity models of refraction profiles $\mathrm{T} 1$ and $\mathrm{T} 2$ are similar and have been interpreted as thinned continental crust intruded by volcanics (McIntosh et al., 2013; 2014; Lester et al., 2014; Eakin et al., 2014). We can first compare velocity profiles in a $\sim 60 \mathrm{~km}$ wide strip located west of the Manila trench, between OBS26 and OBS30 for Profile T2 and between OBS09 and OBS06 for Profile OBS2015-2 (Fig. 1). The velocity profiles are exactly the same down to the depth of $\sim 16 \mathrm{~km}$, which corresponds to the $7.0 \mathrm{~km} / \mathrm{s}$ iso-velocity curve (Fig. 12). The Moho interface is located near the $7.5 \mathrm{~km} / \mathrm{s}$ iso-velocity curve in the above two profiles, and is $2-3 \mathrm{~km}$ deeper than in Profile T1. The nature of the crust is consequently the same for the three profiles, which is thinned continental crust intruded by volcanics, even if the thickness of the crust might be a little bit larger along Profile T1 (Fig. 12).

However, Profile T1 differs from the two other northern parallel profiles OBS2015-2 and T2, which show different velocity distributions for the lower middle crust, lower crust and upper mantle (Fig. 12). An upper mantle intrusion between OBS03 and OBS06 seems to affect the lower crust and the lower middle crust up to the $6.4 \mathrm{~km} / \mathrm{s}$ iso-velocity curve (Fig. 12). A NE-SW elongated ridge associated with a significant linear positive Free-air anomaly (Fig. 1) cuts across Profile MGL0905_20 very close to the northern end of this ridge and extends to the location between OBS04 and OBS05 on Profile T1. This $\mathrm{N}^{\circ} 45^{\circ}$ elongated ridge has been interpreted as a volcanic ridge (Yeh et al., 2012; Sibuet et al., 2016b) not associated with a clear magnetic anomaly at this 
crossing. However, at its intersection with Profile OBS2001 (between OBS2 and OBS3) this NE-SW elongated ridge is outcropping and interpreted as a volcanic feature by Wang et al. (2006). Therefore, we interpret the T1 deep velocity structure between OBS03 and OBS06 as a volcanic ridge intruded at mid-crustal level (Fig. 12), similar to the basement high imaged on MCS Profile MGL0905_10, at a distance of 250-300 km in Figure 3 of McIntosh et al. (2014).

OBS Profile MGL0905_27 (Lester et al., 2013), located just south of Profile OBS2015-2 only displays only 3 OBSs to the west of the Manila trench (Fig. 1). The Moho depth is at $\sim 16 \mathrm{~km}$ below the southwesternmost OBS with a 2-3 km thick HVL at the base of the crust. Although the plate bends toward the trench, the thickness of the crust remains constant (Lester et al., 2013). Observations from Profiles T2, OBS2015-2 and MGL0905_27 all indicate similar crustal natures and thicknesses to the northeast of the LRTPB.

Figure 13 shows refraction Profile MGL0905_20 and its coincident MCS profile. They cut across refraction profiles T2, OBS2015-2, T1 and MGL0905_27 in the distal part of the margin. The crust is thinned to $4 \mathrm{~km}$ within the failed rift, as previously identified by McIntosh et al. (2014) between OBS11 and 12 at a distance of 150-160 km (Fig. 13). The Moho is identified along the whole MCS profile but not in the refraction data since only upper mantle and crustal first arrivals were used by Lester et al. (2014). The distal margin is imaged southwards to $360 \mathrm{~km}$ near the southern end of MCS Profile MGL905_20 (Fig. 13b), where it is unclear whether the southern extremity of the profile belongs to typical oceanic crust or COT. In contrast to the highly thinned basin, less tilted blocks are imaged in the distal portion of the MCS profile and several crustal volcanic zones with rough basement disrupt the breakup unconformity as between 270 and $300 \mathrm{~km}$ (Lester et al., 2014). The velocity structure is similar to the highly thinned, magmatically intruded 
continental crust in profiles T2, OBS2015-2, T1 and MGL0905_27. The 7.0-7.5 km/s HVL occurs in the distal margin (Lester et al., 2014) between OBS11 and 21 along Profile MGL0905_20, pinching out against the Moho beneath the highly thinned failed rift basin.

\subsection{Location of the COB in the northern SCS}

Several locations of the COB were proposed in the northern SCS. The location of COB1 was based on the magnetic lineations identified in the typical oceanic crust (Taylor and Hayes, 1983; Briais et al., 1993). The location of COB2 should not be adopted since the interpreted magnetic lineations (chrons $\mathrm{C} 15$ to $\mathrm{C} 17$ ) are actually associated with volcanic ridges emplaced through the thinned continental crust between 24 and 17 Ma. The location of COB3 was updated from COB1 by taking into account the interpreted refraction and MCS profiles extending southwards to the limit of the hyper-extended margin (e.g., McIntosh et al., 2014) (Fig. 1). We therefore locate an update COB (as COB4) by using both the newly acquired MCS and refraction data to better define the southern boundary of the thinned continental crust, and also by re-identifying the oldest SCS magnetic lineations, which have not been globally updated since the work of Briais et al. (1993). For this purpose, magnetic lineations were drawn on the Doo et al. (2015) magnetic anomaly map (Fig. 2). We have also simultaneously used information from several other published magnetic anomaly maps (Ishihara and Kisimoto, 1996; Hsu et al., 2004; Yu et al., 2017) and unpublished local magnetic anomaly maps. The first observation is that the COB corresponds to a sharp boundary between low amplitude, irregular shape magnetic anomalies associated with the thinned continental domain and high amplitude, elongated shape magnetic anomalies associated with the oceanic domain, possibly including post-rifting elongated volcanic ridges. In a first approximation, this observation suggests 
that it is most appropriate to interpret the northern SCS margin within the context of a COB rather than COT, even if locally, a narrow COT may exist. A second series of observations shows that: (1) the oldest northernmost oceanic magnetic lineations are EW trending close to the trench and NNE trending further west; (2) Two oceanic FZs trending NS (FZ1) and NNW-SSE (FZ2, already delineated in the basement map of Sun et al. (2016)) are identified. They cannot be active simultaneously because they trend differently. If the FZ2 would therefore be related to the first episode of SCS opening (from chrons C11 to C10 identified by Briais et al. (1993), the FZ1 is related to the second episode of SCS opening. Therefore, chrons C12? to C10? located west of the Manila trench in Fig. 2 are probably younger (possibly C9 and younger chron in Fig. 2). This implies a ridge jump transferred the older magnetic lineations on the SCS conjugate side presently located within the Manila slab (Sibuet et al., 2016). This preliminary work shows the need for a new kinematic scheme for the earlier SCS opening. The location of the COB can be checked and confirmed near IODP holes U1432 and U1500 (Fig. 2). MCS, magnetic and drilling data show that the COB is located between IODP U1435 and U1432 (Fig. 7 in Li et al., 2015) and near IODP U1500 (Ding et al., 2018; Sun et al., 2018; Zhao et al., 2018b).

\section{Geodynamic interpretation}

\subsection{Does the Luzon-Ryukyu Transform Plate Boundary (LRTPB) exist in the}

\section{northeastern SCS?}

The LRTPB was defined by Sibuet et al. (2002). This feature extends from the continental shelf edge at the intersection between two consecutive segments of margins trending $\sim \mathrm{N} 075^{\circ}$ and $\sim \mathrm{N} 025^{\circ}$, and follows the Taiwan canyon and intersects the Manila trench at $20^{\circ} \mathrm{N}$ latitude where a change in 
trend of the Manila trench occurs (Fig. 1). The northwestern portion of this feature is marked by a negative Free-air anomaly southeastward to $21.5^{\circ} \mathrm{N}$ latitude. Further south, this feature was defined from eight MCS profiles specifically collected for this purpose. The basement depth map (Sibuet et al., 2002) shows that the basement is consistently $0.8 \mathrm{~km}$ deeper in the northeast compared to southwest of this feature, despite local basement depth variations along individual profiles that are much larger than $0.8 \mathrm{~km}$. Profile OBS2015-2, for example, shows that the mean depth on both sides of the LRTPB differs by $\sim 1$ second two-way travel time (Fig. 3), but it is almost impossible to independently identify its precise location. As previously established, this feature is entirely located within the thinned continental domain. Therefore, the LRTPB can no longer be interpreted as a feature located in the oceanic crust that was active during the SCS opening.

Between this feature and COB4, the nature of crust is thinned continental crust intruded by $\sim \mathrm{N} 045^{\circ}$ oriented volcanic ridges separated by elongated depressions (McIntosh et al., 2014). None of these structural trends extended in the northeast of the feature (Fig. 1). South of COB4, the nature of the crust is oceanic with $\sim \mathrm{N} 085^{\circ}$ trending seafloor spreading magnetic lineations (Fig. 1). North of the LRTPB, three $\mathrm{N} 110^{\circ}$ oriented trends established from seismic reflection and magnetic data were previously interpreted as fracture zones (Sibuet et al., 2002) (Fig. 1). As FZs are only located in oceanic domains, a more reasonable interpretation is that these $\mathrm{N} 110^{\circ}$ trends are volcanic ridges intruded through deeply penetrating normal faults resulting from the continental crust thinning. Note that the failed rift defined by McIntosh et al. (2014) is approximately parallel to Profile MGL0905_10 and is located $\sim 10 \mathrm{~km}$ north of this profile (Fig. 1). The failed rift extends from the LRTPB to the deformation front (DF in Fig. 1) of the accretionary prism at northernmost Manila trench, and even extends slightly into the Manila slab. Therefore, all structural features located on 
either side of the LRTPB show independent trends and do not cut across the LRTPB. This strengthens the notion that the tectonic significance of the LRTPB is different from that originally proposed by Sibuet et al. (2002), and should be updated. We suggest that this feature is a transfer zone that separates two consecutive segments of continental margins with different orientations, instead of a transform plate boundary within the oceanic crust. The presence of this transfer zone is restricted to the thinned continental domain and does not continue into the oceanic domain. As stretching factors may be different on each side of a transfer zone, the horizontal offset of a transfer zone may vary along the transfer zone, in contrast to a shear plate boundary where the horizontal offset remains constant along its trend.

In the northeastern SCS, we now call this transfer zone the Taiwan transfer zone (hereinafter referred to as TTZ) instead of the LRTPB (Figs. 1 and 2). The TTZ separates two consecutive segments of continental margins oriented $\sim \mathrm{N} 075^{\circ}$ northeast and $\sim \mathrm{N} 025^{\circ}$ southwest of the TTZ. It extends from the shelf edge to the Manila trench, at the intersection point between the COB4 and the TTZ (Fig. 1). Three wide-angle deep seismic profiles (OBS2015-2, T1 and MGL0905_20) cut the TTZ (Figs. 12 and 13) near OBS 6, 5 and 19 respectively. Unfortunately refraction profile T1 and its coincident MCS profile do not properly image the lower crust and Moho because of an intruded volcanic body. Both refraction profiles OBS2015-2 and MGL0905_20 (Figs. 12b and 13a) show the presence of a smooth Moho at depth of $\sim 19 \mathrm{~km}$ on both sides of the TTZ, though a mean $\sim 15 \mathrm{~km}$ spacing between OBSs might cause the lack of lateral resolution. In contrast, along OBS2015-2 Profile, the HVL on the eastern side of the TTZ is two times as thick as that on the western side (Fig. 12b). As the basement depth is $0.8 \mathrm{~km}$ deeper on the eastern side compared with the western side of the TTZ (Fig. 3b), the resulting amount of extension, and thus underplating (Bown and White, 1995; Le 
Pichon and Sibuet, 1981), is larger on the eastern side of the TTZ. To the south, along Profile MGL0905_20, the HVL thickness increases on the western side of the TTZ (Fig. 13b) in the distal part of the margin, which is another geodynamic province where tilted fault bocks are rare.

The new images and findings from densely-conducted refraction and reflection surveys during the last decade allow us to re-interpret previously-acquired datasets and extend insights from a crucial portion of the SCS into a larger geodynamic context. The presence of post-rifting volcanic ridges and transfer zones might also be observed elsewhere along the northern SCS margin.

\subsection{Does the wide thinned continental domain of the northeastern SCS extend into the}

\section{Manila slab?}

We further integrate our analysis of the northeastern SCS lithospheric structure with tomographic constraints on the subducted, missing portion of the SCS (i.e. Manila slab) from Wu et al. (2016). The nature and distribution of lithospheric boundaries within the subducted SCS is an unsolved puzzle for both SCS geodynamics and reconstructions of the Taiwan orogen and the Philippine Sea plate (e.g., Suppe, 1984; Sibuet et al., 2002; Byrne and Liu, 2002; Huang et al., 2006; Lee et al., 2015; Wu et al., 2016). Classic geological models of southern Taiwan typically show an ENE-striking COB within the restored Manila slab (e.g., Suppe, 1984; Byrne and Liu, 2002; Huang et al., 2006). These models imply an oblique, southward-propagating collision occurred at $\sim 8 \mathrm{Ma}$ between the Eurasian-SCS COB and incoming Luzon arc (e.g., Suppe, 1984; Byrne and Liu, 2002; Huang et al., 2006). The southward-propagating Taiwan collision model has been highly influential in studies of exhumation processes, erosion rates, foreland basin evolution, and the development of a steady-state orogeny (e.g., Willett et al., 2003; Huang et al., 2006). In contrast, a recent model 
suggests the northeast Eurasian-SCS COB did not continue ENE-ward but stepped northwards just east of the present Manila trench to form a $\sim 300 \mathrm{~km}$-long, N-S oriented segment (Lee et al., 2015). This model implied that Taiwan was formed by a near-parallel, simultaneous collision between a N-S Eurasian-SCS COB and the Luzon arc (Lee et al., 2015). Evidence for this 'simultaneous collision' model included 62 new, completely reset zircon fission-track ages and the onset of rapid tectonic subsidence in both northern and southern parts of the foreland basin that were dated at $~ 5-6 \mathrm{Ma}$ (Lee et al., 2015).

Wu et al. (2016) described a "flexural unfolding" methodology to estimate the pre-subduction geometry of a slab by structurally restoring a mapped slab to the Earth surface. The method allowed tomographic $P$-wave perturbation $(d V p)$ variations within the mapped slab to be extracted and preserved during slab unfolding (Wu et al., 2016). Tomographic analysis of the Manila slab from MITP08 $P$-wave global seismic tomography (Li et al., 2008) showed the Manila mid-slab anomaly extended past the Benioff zone to a maximum depth of $450 \mathrm{~km}$ (Fig. S6). The Manila slab was mapped $\sim 100 \mathrm{~km}$ north of Taiwan (e.g., Fig. S6b and c) based on interpreted subduction and delamination of the Eurasian continental lithosphere under Taiwan from tomographic images (Suppe et al., 2011). Serial tomographic sections showed faster $d V p$ velocities within the mapped Manila slab (between $0.8 \%$ to $-0.5 \% d V p$ ) relative to the surrounding mantle, with noticeable velocity variations within the slab anomaly (Figs. S6a to S6d). These velocity variations were displayed along the unfolded Manila slab from MITP08 by Wu et al. (2016) (Figs. 14a and 15). For comparison, we show newly extracted velocities along the unfolded Manila slab from three other published $P$ - and $S$-wave tomographic models (Amaru, 2007; Koulakov, 2011) (Fig. 14). Small differences in the unfolded Manila slab boundaries between Figures 14 and 15 may be attributed to different unfold 
parameters. The figure 14 is obtained by unfolding the Manila slab to an orthogonal Earth surface, while the Figure 15 is obtained by unfolding the slab to a more sophisticated spherical Earth model. It should be noted that spatial resolution of the tomographic images quoted in our section 5.2 are dependent on the specific tomography model but generally have a $100 \mathrm{~km}$ resolution. This resolution is significantly coarser than the results shown earlier from Section 4. Furthermore, the tomographic velocity variations within the uppermost 75 to $100 \mathrm{~km}$ of the Manila slab (i.e., the grey strip near the Manila trench in Figs. 14 and 15) are generally unreliable due to crustal corrections. Therefore, our integration of the Manila slab unfolding with the easternmost SCS COB location from Section 4 has obvious limitations but is still informative given the scale of uncertainty in current SCS geodynamics and Taiwan plate collision reconstructions models, as outlined above.

The unfolded Manila slab from Wu et al. (2016) is reconstructed to the SCS along the Manila trench and extends 400-500 km east of the Manila trench (Fig. 15). The SCS oceanic domain, characterized by $\mathrm{N} 055^{\circ}, \mathrm{N} 075^{\circ}$ and $\mathrm{N} 085^{\circ}$ seafloor spreading directions has been delimited by pink, yellow and light blue areas (Sibuet et al., 2016b), respectively. Outside the continental shelves and the oceanic domain, the remaining parts of the SCS are thinned continental domains. The newly established COB4 (Fig. 1) appears as a red line in Fig. 15. The white and purple strip that is just east of the trench and $<100 \mathrm{~km}$ wide (Fig. 15) does not contain reliable tomographic data due to the crust correction within the global tomography and should be ignored. East of this strip, positive $d V p$ values generally correspond to oceanic domains, while slightly negative values $(-0.1 \% d V p)$ correspond to thinned continental domains at the SCS northern and southern conjugate margins. The continuous portion of red line located beneath the present-day southwestern Ryukyu arc defines the location of the $\mathrm{COB}$ in this area (Fig. 15). 
The slower velocities near the northern COB (Fig. 15) appear to be a particularly robust feature within the tomography and also appear within the other tomographic models (Figs. 14a and d). The $\sim \mathrm{N}-\mathrm{S}$ dashed red line joins to the south the eastern prolongation of COB below the Manila trench (Fig. 15). The location of this boundary is less well-defined due to its location near the upper 100-km artifact zone but is consistent with subduction of thinned continental crust beneath the northern Manila subduction zone (McIntosh et al., 2013; 2014; Lester et al., 2014; Eakin et al., 2014). Thus, the red line located in the eastern prolongation of $\mathrm{COB}$ separates two domains: 1) to the north, below the western Ryukyu subduction zone, larger negative $d V p$ values correspond to continental and thinned continental crusts; 2) to the south, the wide area characterized by positive $d V p$ values corresponds to a robust oceanic domain (Fig. 15). One exception is the $\sim 120-\mathrm{km}$ long E-W narrow feature at $\sim 21^{\circ} \mathrm{N}$ latitude (Fig. 15). Here the slightly slower $-0.1 \% d V p$ velocities show similarities to tomographic velocities near the northern $\mathrm{COB}$ and could potentially indicate a tomographic artifact or a rifted fragment (Fig. 15). However, this local slow feature was not well-reproduced across the other tomographic models (Figs. 14b and c) and therefore this interpretation is tentative, at best. Overall, our results suggest the $\mathrm{COB}$ within the Manila slab is not located in the E-W prolongation of COB but is $\sim 400 \mathrm{~km}$ offset toward the north (Fig. 15). Our new identification of a $\sim \mathrm{N}-\mathrm{S}$ border of the Eurasian continent southeast of Taiwan, outboard of the thicker Eurasian continental crust, supports the recent simultaneous Taiwan collision model of Lee et al. (2015) and challenges the classic Taiwan collision model (Suppe, 1984; Byrne and Liu, 2002; Huang et al., 2006).

To the south, our preferred extinct SCS spreading axis extends east of the existing SCS ridge shown by He et al. (2016) and Zhao et al. (2018b), following the red thick dashed line located north of the $18^{\circ} \mathrm{N}$ area with $d V p$ values close to $0.3 \%$ (Fig. 15). The $18^{\circ} \mathrm{N}$ slow velocity domain also appeared 
in the other tomography (Fig. 14) and could also be otherwise interpreted as a slab window or hot zone within the Manila slab due to subduction during or shortly after spreading.

These findings partly contradict the kinematic reconstructions of Sibuet et al. (2002), not because the eastern extension of the SCS at the end of the SCS opening is located in the northern prolongation of the Philippine trench as proposed in Wu et al. (2016) reconstructions, but because the detailed plate kinematic arrangements were wrong. The domain located between the TTZ and the Manila trench was previously considered as a portion of the oceanic proto-SCS rather than thinned continental crust. East of the Manila trench, the northern and southern Taiwan plates proposed by Sibuet et al. (2002) are no longer required as the SCS extinct spreading axis extended along the whole SCS to $124^{\circ} \mathrm{E}$ longitude, separating the SCS into two main plates during the SCS opening.

We have demonstrated that only two plates were involved during the SCS opening. Therefore, the kinematic arrangement of plates during and at the end of the SCS opening is much simpler than previously proposed, mostly because recent wide-angle seismic reflection/refraction data allow us to clearly establish the thinned continental nature of the crust in the northeastern SCS.

\section{Conclusions}

The E-W oriented OBS2015-2 wide-angle seismic reflection and refraction profile was shot at equal distance between refraction profiles $\mathrm{T} 1$ and T2. Velocity models obtained by using RayInvr forward and Tomo $2 d$ inversion methods, show that the crust along this profile is $\sim 12-15 \mathrm{~km}$ thick and is thinned continental crust intruded by post-rifting volcanics. The crust is not oceanic crust based on the presence of sedimentary continental tilted fault blocks. Where both breakup and regional unconformities are absent, volcanic intrusions are present and associated with magnetic anomalies of 
different amplitude. At the base of the crust, the HVL is interpreted as underplating.

Newly acquired MCS and refraction data and a re-identification of the oldest SCS magnetic lineations based on published magnetic anomaly maps were used together to better define the southern boundary of the thinned continental crust. The main boundary between low amplitude, irregular shape magnetic anomalies associated with thinned continental domain and high amplitude, elongated shape magnetic anomalies associated with the oceanic domain, possibly including post-rifting elongated volcanic ridges suggests the presence of a continent-ocean boundary (COB) rather than a continent-ocean transition zone (COT) within the region. The location of the COB was confirmed near IODP holes U1432 and U1500 and was continuously drawn from this location to the Manila trench.

The Taiwan transfer zone (TTZ) separates two consecutive segments of continental margins with different orientations $\left(\sim \mathrm{N} 075^{\circ}\right.$ and $\left.\sim \mathrm{N} 025^{\circ}\right)$ and is not an oceanic plate boundary as previously proposed. The TTZ is a linear feature following the Taiwan Canyon, with a large associated negative Free-air anomaly in its northern portion and further south corresponds to a $0.8 \mathrm{~km}$ vertical offset between its two sides, as observed on the shallow part of Profile OBS2015-2. At depth, the thickness of the high-velocity layer (HVL) is double on the eastern side of the TTZ compared with the western side, suggesting a relationship between the mean depth of basement, the amount of extension and the HVL thickness. Between the TTZ and the COB, none of the structural trends (volcanic ridges and elongated depressions) extend in the northeast of the TTZ. Between the TTZ and the Manila trench, similar structural trends with different orientations do not cross-cut the TTZ, strengthening the existence of the TTZ as a transfer zone, which separates two consecutive segments of continental margins from the shelf edge to its intersection with the COB and the Manila trench. Thus, the TTZ 
does not continue into the oceanic domain and its presence is restricted to the thinned continental domain.

The unfolded Manila slab is attached to the SCS along the Manila trench and extends 400-500 $\mathrm{km}$ east of the Manila trench. Mid-slab positive $d V p$ values generally correspond to oceanic domains while negative values correspond to thinned continental domains. The eastern prolongation of the COB separates a thinned continental crust characterized by negative $d V p$ values below the western Ryukyu subduction zone to the north from a wide area with positive $d V p$ values corresponding to typical oceanic crust to the south (Fig. 15). Thus, the boundary between subducted oceanic and thinned continental crusts extends from the Manila trench to east of the present-day Taiwan across a $\sim 400$ km-long NS trending segment, suggesting that the eastern border of the Eurasian continent was parallel to the Luzon arc before collision. The parallelism of these two features supports the notion that the Taiwan collision was near-simultaneous along strike rather than southward propagating as previously hypothesized.

Based on recently acquired MCS and refraction profiles, we propose a reconstructed SCS geometry at the end of seafloor spreading with a newly established COB from the legs 367-368 IODP area to east of the present-day Taiwan. These new findings allow us to reconsider the interpretation of previously acquired datasets in the northeastern SCS and to provide new constraints for both the SCS geodynamics at the end of spreading and its later tectonic evolution. The insights for the northeastern SCS shown in this study suggests that post-rift volcanic ridges and transfer zones might be also observed elsewhere along the northern SCS margin.

\section{Acknowledgements}


We are grateful to the crew of the $R / V$ Shiyan 2 as well as scientists and technicians for their precious involvement during the cruise. Insightful discussions with Chunfeng $\mathrm{Li}$, Min $\mathrm{Xu}$, and Ting Yang are acknowledged. We thank late Kirk McIntosh for providing T1 and T2 numerical tomographic models shown in Figure 12. The GMT software (Wessel and Smith, 1995) was used in this study. We are particularly grateful to three anonymous reviewers, Ling Chen and Zheng-Xiang Li for their careful reviews and scientific suggestions, which help to improve the manuscript greatly. We acknowledge Shu-Kun Hsu and Wen-Bin Doo for providing a copy of their magnetic anomaly map of East Asia. Jonny Wu acknowledges John Suppe for discussions on tomographic velocities within the Manila slab and interpretation of the region under northern Taiwan. Jonny Wu gratefully acknowledges use of Gocad software through the Paradigm Geophysical grant program. This work is supported by the Chinese National Natural Science Foundation (contracts 91428204, 41674092, 41730532 and 41576070) and Guangdong NSF team project (contracts 2017A030312002). All OBS data shown in this paper can be downloaded at https://pan.baidu.com/s/4dFEV9rr.

\section{References}

Amaru, M.L., 2007. Global travel time tomography with 3-D reference models. Geologica Ultraiectina 274, 1-174.

Ao, W., Zhao, M.H., Qiu X.L., Li, J.B., Ruan, A.G., Li, S.J., Zhang, J.Z., 2010. The correction of shot and OBS position in the 3D seismic experiment of the SW Indian Ocean Ridge. Chin. J. Geophys. 53, 1072-1081. http://dx.doi.org/10.1002/cjg2.1577.

Barckhausen, U., Engels, M., Franke, D., Ladage, S., Pubellier, M., 2014. Evolution of the South China Sea: Revised ages for breakup and seafloor spreading. Mar. Pet. Geol. 58, 599-611. 
http://dx.doi.org/10.1016/j.marpetgeo.2014.02.022.

Bown, J.W., White, R.S., 1995. Effect of finite extension rate on melt generation at rifted continental margins. J. Geophys. Res. 100, 18011-18029.

Briais, A., Patriat, P., Tapponnier, P., 1993. Updated interpretation of magnetic anomalies and seafloor spreading stages in the South China Sea: Implications for the Tertiary tectonics of southeast Asia. J. Geophys. Res. 98, 6299-6328.

Byrne, T.B., Liu, C.-S., 2002. Geology and geophysics of an arc-continent collision, Taiwan. Geol. Mag. 140, 729-730. http://dx.doi.org/ 10.1017/S0016756803258830.

Cameselle, A., Ranero, C.R., Franke, D., Barckhausen, U., 2015. The continent-ocean transition on the northwestern South China Sea. Basin Res. 29, 73-95. http://dx.doi.org/10.1111/bre.12137.

Christensen, N.I., Mooney, W.D., 1995. Seismic velocity structure and composition of the continental crust: A global view. J. Geophys. Res. 100, 9761-9788.

Davy, R.G., Minshull, T.A., Bayrakci, G., Bull, J.M., Klaeschen, D., Papenberg, C., Reston, T.J., Sawyer, D.S., Zelt, C.A., 2016. Continental hyperextension, mantle exhumation, and thin oceanic crust at the continent-ocean transition, West Iberia: New insights from wideangle seismic. J. Geophys. Res. Solid Earth 121, 3177-3199. http://dx.doi.org/10.1002/2016JB012825.

Dean, S.M., Minshull, T.A., Whitmarsh, R.B., Louden, K.E., 2000. Deep structure of the ocean-continent transition in the southern Iberia Abyssal Plain from seismic refraction profiles: The IAM-9 transect at $40^{\circ} 200^{\prime} \mathrm{N}$. J. Geophys. Res. 105, 5859-5885. http://dx.doi.org/10.1029/1999JB900301.

Ding, W.W., Sun Z., Dadd, K., Fang, Y.X., Li, J.B., 2018. Structures within the oceanic crust of the 
central South China Sea basin and their implications for oceanic accretionary processes. Earth Planet. Sci. Lett. 488, 115-125. https://doi.org/10.1016/j.eps1.2018.02.011.

Doo, W.-B, Hsu, S.-K., Armada, L., 2015. New magnetic anomaly map of the East Asia with some preliminary tectonic interpretations. Terr. Atmos. Ocean. Sci. 26, 73-81. http://doi.org/10.3319/TAO.2014.08.19.07(GRT).

Eakin, D.H., McIntosh, K.D., Van Avendonk, H.J.A., Lavier, L., Lester, R., Liu, C.-S., Lee, C.-S., 2014. Crustal-scale seismic profiles across the Manila subduction zone: The transition from intraoceanic subduction to incipient collision. J. Geophys. Res. 119, 1-17. http://dx.doi.org/10.1002/2013JB010395.

Franke, D., 2013. Rifting, lithosphere breakup and volcanism: Comparison of magma-poor and volcanic rifted margins. Mar. Pet. Geol. 43, 63-87. http://dx.doi.org/10.1016/j.marpetgeo.2012.11.003.

Hamilton, E.L., 1978. Sound velocity-density relations in sea-floor sediments and rocks. J. Acoust. Soc. Am. 63, 366-377.

He, E.Y., Zhao, M.H., Qiu, X.L., Sibuet, J.-C., Wang, J., Zhang, J.Z., 2016. Crustal structure across the post-spreading magmatic ridge of the East Sub-basin in the South China Sea: Tectonic significance. J. Asian Earth Sci. 121, 139-152. http://dx.doi.org/10.1016/j.jseaes.2016.03.003.

Huang, C.-Y., 2006. Temporal and spatial records of active arc-continent collision in Taiwan: A synthesis. Geol. Soc. Amer. Bull. 118, 274-288. http://dx.doi.org/10.1130/B25527.1.

Hsu, S.-K., Yeh, Y.-C., Doo, W.-B., Tsai, C.-H., 2004. New bathymetry and magnetic lineations identifications in the northernmost South China Sea and their tectonic implications. Mar. Geophys. Res. 25, 29-44. http://dx.doi.org/10.1007/s11001-005-0731-7. 
Ishihara, T., Kisimoto, K., 1996. Magnetic anomaly map of East Asia 1:4.000.000, [CD - ROM]. Geological Survey of Japan and Coordinating Committee for Costal and Offshore Geoscience Programs in East and Southeast Asia (CCOP).

Jian, Z., Larsen, H.C., Alvarez Zarikian, C.A., and the Expedition 368 Scientists, 2018. Expedition 368 Preliminary Report: South China Sea Rifted Margin. International Ocean Discovery Program. https://doi.org/10.14379/iodp.pr.368.2017

Kashubin, S.N., Petrov, O.V., Rybalka, A.V., Milshtein, E.D., Shokalsky, S.P., Verba, M.L., Petrov, E.O., 2017. Earth's crust model of the South-Okhotsk Basin by wide-angle OBS data. Tectonophysics 710-771, 37-55. http://dx.doi.org/10.1016/j.tecto.2016.11.021.

Korenaga, J., Holbrook, W.S., Kent, G.M., Kelemen, P.B., Detrick, R.S., Larsen, H.-C., Hopper, J.R., Dahl-Jensen, T., 2000. Crustal structure of the southeast Greenland margin from joint refraction and reflection seismic tomography. J. Geophys. Res. 105, 21591-21614.

Koulakov, I., 2011. High-frequency $\mathbf{P}$ and S velocity anomalies in the upper mantle beneath Asia from inversion of worldwide traveltime data. J. Geophys. Res. 116, B04301. http://dx.doi.org/10.1029/2010JB007938.

Lee, Y.-H., Byrne, T., Wang, W.-H., Lo, W., Rau, R.-J., Lu, H.-Y., 2015. Simultaneous mountain building in the Taiwan orogenic belt. Geology 43, 451-454. http://dx.doi.org/10.1130/G36373.1.

Le Pichon, X., Sibuet, J.-C., 1981. Passive margins: A model of formation. J. Geophys. Res. 86, 3708-3720. http://dx.doi.org/10.1029/JB086iB05p03708.

Lester, R., McIntosh, K., Van Avendonk, H.J.A., Lavier, L., Liu, C.-S., Wang, T.-K., 2013. Crustal accretion in the Manila trench accretionary wedge at the transition from subduction to 
mountain-building in Taiwan. Earth Planet. Sci. Lett. 375, 430-440. http://dx.doi.org/10.1016/j.eps1.2013.06.007.

Lester, R., Van Avendonk, H.J.A., McIntosh, K., Lavier, L., Liu, C.-S., Wang, T.-K., Wu, F., 2014. Rifting and magmatism in the northeastern South China Sea from wide-angle tomography and seismic reflection imaging. J. Geophys. Res. 119, 2305-2323. http://dx.doi.org/10.1002/2013JB010639.

Li, C., Hilst, R.D., Engdahl, E.R., Burdick, S., 2008. A new global model for P wave speed variations in Earth's mantle. Geochem. Geophys. Geosyst. 9, Q05018. http://dx.doi.org/10.1029/2007GC001806.

Li, C.F., Xu, X., Lin, J., Sun, Z., Zhu, J., et al., 2014. Ages and magnetic structures of the South China Sea constrained by deep tow magnetic surveys and IODP Expedition 349. Geochem. Geophys. Geosyst. 15, 4958-4983. http://dx.doi.org/10.1002/2014GC005567.

Li, C.F., Lin, J., Kulhanek, D.K., and the Expedition 349 Scientists, 2015. Proceedings of the International Ocean Discovery Program Volume 349. http://dx.doi.org/10.14379/iodp.proc.349.101.2015.

Liu, S.Q., Zhao, M.H., Zhang, J.Z., Sun, L.T., Xu, Y., Zhan, W.H., Qiu, X.L., 2017. OBS seismic data processing of the Manila trench subduction zone $\left(21^{\circ} \mathrm{N}\right)$ and some preliminary results. J. Trop. Oceanogr. 36, 60-69. http://dx.doi.org/10.11978/2016058. (in Chinese with English abstract).

Lüdmann, T., Wong, H. K., 1999. Neotectonic regime on the passive continental margin of the $\begin{array}{lllll}\text { northern } & \text { South } & \text { China } & \text { Sea. } & \text { Tectonophysics }\end{array}$ https://doi.org/10.1016/S0040-1951(99)00155-9. 
McIntosh, K., Lavier, L., Van Avendonk, H.J.A., Lester, R., Eakin, D., 2014. Crustal structure and inferred rifting processes in the northeast South China Sea. Mar. Pet. Geol. 58, 612-626. http://dx.doi.org/10.1016/j.marpetgeo.2014.03.012.

McIntosh, K., Van Avendonk, H.J.A., Lavier, L., Lester, W.R., Eakin, D., Wu, F., Liu, C.-S., Lee, C.-S., 2013. Inversion of a hyper-extended rifted margin in the southern Central Range of Taiwan. Geology 41, 871-874. https://doi.org/10.1130/G34402.1.

Nissen, S.S., Hayes, D.E., Buhl, P., Diebold, J., Bochu, Y., Zeng, W., Chen, Y., 1995. Deep penetration seismic soundings across the northern margin of the South China Sea. J. Geophys. Res. 100, 22407-22433.

Qiu, X.L., Ye, S.Y., Wu, S.M., Shi, X.B., Zhou, D., Xia, K.Y., Flueh, E.R., 2001. Crustal structure across the Xisha Trough, northwestern South China Sea. Tectonophysics 341, 179-193. http://dx.doi.org/10.1016/S0040-1951(01)00222-0.

Sandwell, D.T., Gracia, E., Soofi, K., Wessel, P., Chandler, M., Smith, W.H.F., 2013. Towards 1 mGal global marine gravity from CryoSat-2, Envisat, and Jason-1. The Leading Edge 32, 892899. https://doi.org/10.1190/tle32080892.1.

Sibuet, J.-C., Hsu, S.-K., Pichon, X., Le Formal, J.-P., Reed, D., Moore, G., Liu, C.-S., 2002. East Asia plate tectonics since 15 Ma: Constraints from the Taiwan region. Tectonophysics. 344, 103-134. https://doi.org/10.1016/S0040-1951(01)00202-5.

Sibuet, J.-C., Yeh, Y.-C., Lee, C.-S., 2016a. Geodynamics of the South China Sea. Tectonophysics 692, 98-19. http://dx.doi.org/10.1016/j.tecto.2016.02.022.

Sibuet, J.-C., Klingelhoefer, F., Huang, Y.-P., Yeh, Y.-C., Rangin, C., Lee, C.-S., Hsu, S.-K., $2016 b$. Thinned continental crust intruded by volcanics beneath the northern Bay of Bengal. Mar. Pet. 
Geol. 77, 471-486. http://dx.doi.org/10.1016/j.marpetgeo.2016.07.006.

Sibuet, J.-C., Tucholke, B., 2012. The geodynamic province of transitional crust adjacent to magma-poor continental margins. Geological Society, London, Special Publications 369, 429-452. https://doi.org/10.1144/SP369.15.

Sun, Z., Stock, J., Jian, Z.M., McIntosh, K., Alvarez-Zarikian, C.A., Klaus, A., 2016. Expedition 367/368 Scientific Prospectus: South China Sea Rifted Margin. International Ocean Discovery Program. http://dx.doi.org/10.14379/iodp.sp.367368.2016.

Sun, Z., Stock, J., Klaus, A., and the Expedition 367 Scientists, 2018. Expedition 367 Preliminary Report: South China Sea Rifted Margin. International Ocean Discovery Program. http://dx.doi.org/10.14379/iodp.pr.367.2017.

Suppe, J., 1984. Seismic interpretation of the compressively reactivated normal fault near Hsinchu, western Taiwan. Petrol. Geol. Taiwan 20, 85-96.

Suppe, J., Carena, S., Wu, Y.-M., Ustaszewski, K., 2011. Subducted lithosphere, slab tearing and continental delamination under Taiwan: arc-continent collision at the junction of quasi-orthogonal subduction systems. AGU Fall Meeting 2011 Abstract, San Francisco, USA.

Taylor, B., Hayes, D., 1983. Origin and history of the South China Sea basin. The Tectonic and Geologic Evolution of Southeast Asian Seas and Islands: Part 2. Geophys. Monogr. Series 27, $23-56$.

Taylor, B., 2017. The rifting to spreading evolution of Marginal basins. 2017 AGU Fall Meeting Abstract, T32A-02, New Orleans, LA.

Wang, K.-L., Lo, Y.-M., Chung, S.-L., Lo, C.-H., Hsu, S.-K., Yang, H.-J., Shinjo, R., 2012. Age and geochemical features of dredged basalts from offshore SW Taiwan: The coincidence of 
intra-plate magmatism with the spreading South China Sea. Terr. Atmos. Ocean. Sci. 6, 657-669. http://dx.doi.org/10.3319/TAO.2012.07.06.01(TT).

Wang, T.-K., Chen, M.-K., Lee, C.-S., Xia, K.-Y., 2006. Seismic imaging of the transitional crust across the northeastern margin of the South China Sea. Tectonophysics 412, 237-254. http://dx.doi.org/10.1016/j.tecto.2005.10.039.

Wessel, P., Smith, W.H.F., 1995. New version of the generic mapping tools released. EOS Trans. AGU 76, 329.

White, R.S., McKenzie, D., O'Nions, R.K., 1992. Oceanic crustal thickness from seismic measurements and rare earth element inversions. J. Geophys. Res. 97, 19683-19715. http://dx.doi.org/10.1029/92JB01749.

White, R.S., Smith, L.K., Roberts, A.W., Christie, P.A.F., Kusznir, N.J., et al., 2008. Lower-crustal intrusion on the North Atlantic continental margin. Nature 452, 460-464. http://dx.doi.org/10.1038/nature06687.

Willett, S., Fisher, D., Fuller, C., Yeh, E.-C., Lu, C.-Y., 2003. Erosion rates and orogenic-wedge kinematics in Taiwan inferred from fission-track thermochronometry. Geology 31, 945-948. http://dx.doi.org/10.1130/G19702.1.

Wu, J., Suppe, J., Lu, R., Kanda, R., 2016. Philippine Sea and East Asian plate tectonics since 52 Ma constrained by new subducted slab reconstruction methods, J. Geophys. Res. 121, 4670-4741. http://dx.doi.org/10.1002/2016JB012923.

Wu, J., Suppe, J., 2017. Proto-South China Sea plate tectonics using subducted slab constraints from tomography. J. Earth Sci. (in press). https://doi.org/10.1007/s12583-017-0813-x.

Yao, C.L., Hao, T.Y., Guan, Z.N., Zhang, Y.W., 2003. High-speed computation and efficient storage 
in 3-D gravity and magnetic inversion based on genetic algorithms. Chin. J. Geophys. 46, 252258. http://dx.doi.org/10.1002/cjg2.351.

Yan, P., Zhou, D., Liu, Z.S., 2001. A crustal structure profile across the northern continental margin of South China Sea $\quad$ Tectonophysics $\quad 338$, 1-21. http://dx.doi.org/10.1016/S0040-1951(01)00062-2.

Yeh, Y.-C., Hsu, S.-K., Doo, W.-B., Sibuet, J.-C., Liu, C.-S., Lee, C.-S., 2012. Crustal features of the northeastern South China Sea: Insights from seismic and magnetic interpretations. Mar. Geophys. Res. 33, 307-326. http://dx.doi.org/10.1007/s11001-012-9154-4.

Yeh, Y.-C., Sibuet, J.-C., Hsu, S.-K., Liu, C.-S., 2010. Tectonic evolution of the Northeastern South China Sea from seismic interpretation. J. Geophys. Res. 115, B06103. http://dx.doi.org/10.1029/2009JB006354.

Yu, X., Xue, C., Shi, H., Zhu, W., Liu, Y., Yin, H., 2017. Expansion of the South China Sea basin: Constraints from magnetic anomaly stripes, sea floor topography, satellite gravity and submarine geothermics. Geoscience $\quad$ Frontiers $\quad 8, \quad 151-162$. http://dx.doi.org/10.1016/j.gsf.2015.12.008.

Zelt, C.A., Smith, R.B., 1992. Seismic travel-time inversion for 2-D crustal velocity structure. Geophys. J. Int. 108, 16-34.

Zhang, L., Zhao, M.H., Wang, J., He, E.Y., Ao, W., Qiu, X.L., Xu, H.L., Wei, X.D., Zhang, J.Z., 2013. Correction of OBS position and recent advances of 3D seismic exploration in the central sub-basin of South China Sea. Earth Science-Journal of China University of Geosciences 38, 33-42. doi: 10.3799/dqkx.2013.004.X. (in Chinese with English abstract).

Zhao, M.H., Qiu, X.L., Wang, P., Xia, S.H., Li, Y.M., Xu, H.L., Ye, C.M., Kang, Y., 2008. Large 
volume air-gun and its seismic waveform characters. Chin. J. Geophys. 51, 558-565. http://dx.doi.org/10.1002/cjg2.1229.

Zhao, M.H., Qiu, X.L., Xia, S.H., Xu, H.L., Wang, P., Wang, T.-K., Lee, C.-S., Xia, K.Y., 2010. Seismic structure in the northeastern South China Sea: S-wave velocity and $V \mathrm{p} / V \mathrm{~s}$ ratios derived from three-component OBS data. Tectonophysics 480, 183-197. http://dx.doi.org/10.1016/j.tecto.2009.10.004.

Zhao, M.H., Du, F., Wang, Q., Qiu, X.L., Han, B., Sun, L.T., Zhang, J., Xia, S.H., and Fan, C.Y., 2018 a. Current status and challenges for three-dimensional deep seismic survey in the South China Sea. Earth Sci. http://doi.org/10.3799/dqkx.2018.573. (in Chinese with English abstract).

Zhao, M.H., He, E.Y., Sibuet, J.-C., Sun, L.T., Qiu, X.L., Tan, P.C., Wang, J., 2018b. Post seafloor spreading volcanism in the central east South China Sea and its formation through an extremely thin oceanic crust. Geochem. Geophys. Geosyst. 19. https://doi.org/10.1002/2017GC007034.

Zhao, M.H., Wang, Q., Sun, L.T., Sun, Z., Qiu, X.L., 2017. Significance of deep seismic survey on IODP367-368 in the South China Sea and suggestions for future OBS deployment. International Geophysical Conference Abstracts, 939-940. https://doi.org/10.1190/IGC2017-237.

Zhao, F., Alves, T.M., Wu, S., Li, W., Huuse, M., Mi, L., Sun, Q., Ma, B., 2016. Prolonged post-rift magmatism on highly extended crust of divergent continental margins (Baiyun Sag, South China Sea). Earth Planet. Sci. Lett. 445, 70-91. http://dx.doi.org/10.1016/j.epsl.2016.04.001. 
Table 1 Forward and inversion model parameters.

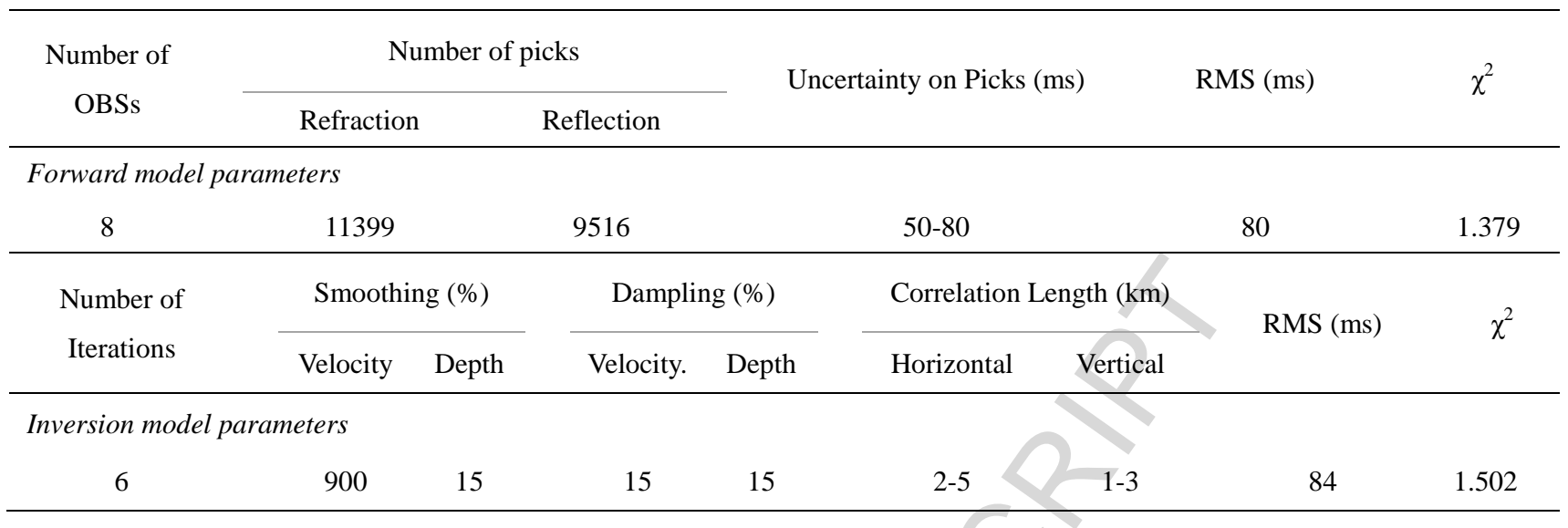


Fig. 1 Locations of wide-angle seismic reflection profiles on a Free-air gravity map (based on Sibuet al., 2016a) of the northeastern South China Sea (SCS) with major tectonic features. Inset depicts the location of the study area. PSP, Philippine Sea plate. Profile OBS2015-2 is shown by a red line with OBS locations in white circles and red numbers. The circle with a cross inside (OBS02) means non-useful data. T1 and T2 wide-angle seismic profiles are from Eakin et al. (2014), MGL0905_20 from Lester et al. (2014), MGL0905_27 from Lester et al. (2013), MGL0905_10 from Yeh et al. (2012), and OBS2001 from Wang et al. (2006) and Zhao et al. (2010). Continent-ocean boundaries, COB1, COB2, COB3 (dark blue dashed lines) and COB4 (red dashed line) are extracted from Briais et al. (1993), Hsu et al. (2004), McIntosh et al. (2014) and modified from this study, respectively. DF, Deformation front; LRTPB, Luzon-Ryukyu transform plate boundary renamed TTZ, Taiwan transfer zone in this paper (see text for explanations). Magnetic lineations (grey solid lines) are from Briais et al. (1993) (chrons 10 to 12) and from Hsu et al. (2004) (chrons 15 to 17). Black crosses and dashed black lines, structural highs (post-rifting intruded volcanic ridges) and elongated depressions are from Sibuet et al. (2016a). Failed rift (black and white diamonds) is from McIntosh et al. (2014). Manila trench, black line with triangles.

Fig. 2 Location of the continent-ocean boundary COB4 on the magnetic anomaly map of Doo et al. (2015). Inset depicts the location of Fig. 2. PSP, Philippine Sea plate. COB1, COB2, COB3 (dark blue dashed lines) and COB4 (red dashed line) are extracted from Briais et al. (1993), Hsu et al. (2004), McIntosh et al. (2014) and defined by this study, respectively. Magnetic lineations (black and closely-spaced dashed lines for negative and positive anomalies, respectively) established by using informations from all published magnetic anomaly maps (Ishihara and Kisimoto 1996; Hsu et al., 2004; Doo et al., 2015; Yu et al., 2017) and unpublished local magnetic anomaly maps. FZ1 and FZ2 are oceanic fracture zones. Other legends as in Fig.1.

Fig. 3 Initial velocity model for RayInvr based on the seismic reflection profile. (a) Observed Free-air gravity and magnetic anomalies along Profile OBS2015-2. (b) Single channel profile extracted from MCS Profile OBS2015-2. TWT, two-way travel time. (c) Initial depth converted model for RayInvr code. The model consists of six layers: seawater, sediment 1, sediment 2, upper crust, lower crust and upper mantle with velocities of $1.5 \mathrm{~km} / \mathrm{s}, 1.8-2.5 \mathrm{~km} / \mathrm{s}, 3.0-3.5 \mathrm{~km} / \mathrm{s}, 5.0-6.4$ $\mathrm{km} / \mathrm{s}, 6.4-6.9 \mathrm{~km} / \mathrm{s}, 8.0-8.2 \mathrm{~km} / \mathrm{s}$, respectively. Arrows indicate the locations of LRTPB (Sibuet et al., 2002), the intersection with MGL0905_20 (Lester et al., 2014), and the Manila trench along Profile OBS2015-2.

Fig. 4 Ray-tracing and travel-times simulations for OBS01 along Profile OBS2015-2. (a) Vertical component of the seismic record section with a $6.0 \mathrm{~km} / \mathrm{s}$ reduced velocity. (b) Observed travel-time (color lines) and calculated travel-time curves (black lines) from the final model. (c) Ray-tracing simulation. The different colored ray paths correspond to the different colored travel times in (b). 
Fig. 5 Ray-tracing and travel-times simulations for OBS04 along profile OBS2015-2. Other legends as in Fig. 4.

Fig. 6 Ray-tracing and travel-times simulations for OBS08 along profile OBS2015-2. Other legends as in Fig. 4.

Fig. 7 Final forward P-wave velocity structure. Yellow circles are OBS locations. (a) Final forward velocity model by using RayInvr software. The thick pink segments indicate where the Moho interface is constrained by PmP arrivals. The blue layer is the HVL. The black arrow is the intersection with Profile MGL0905_20. (b) Ray coverage density on a $0.5 \mathrm{~km} \times 0.25 \mathrm{~km}$ grid corresponding to the above velocity model. (c) Velocity perturbation model. (d) Picked (colored) and calculated (black) travel times of seismic phases for all OBS receivers in the model.

Fig. 8 Final inverted $P$-wave velocity model. (a) Final inversion velocity model by using Tomo $2 d$ code with a floating Moho interface. The dashed red line shows the Moho interface from the RayInvr model in Fig. 7a. Black arrows is the intersection with Profile MGL0905_20. (b) Derivative weight sum (DWS) of Profile OBS2015-2 shows ray coverage throughout the model. (c) Standard deviations of $P$-wave velocities, derived by inverting perturbed starting models.

Fig. 9 Recovered velocity perturbations from checkerboard tests for Profile OBS2015-2. Checkerboard tests after inversion with velocity perturbation anomalies of $\pm 5 \%$ (positive in green and negative in red). (a), (b) and (c) are three panels showing resolved checkerboard patterns with different sizes of cells: $30 \times 13 \mathrm{~km}, 20 \mathrm{~km} \times 13 \mathrm{~km}$, and $20 \mathrm{~km} \times 8 \mathrm{~km}$. The threshold checkerboard cells is $20 \mathrm{~km} \times 13 \mathrm{~km}$ in (b).

Fig. 10 Free-air gravity modeling along Profile OBS2015-2. (a) Observed (green) and calculated (red) Free-air gravity anomalies. Water depth (blue) extracted from the single-channel seismic profile along Profile OBS2015-2. (b) Best fitting 2-D gravity model of Profile OB2015-2 with densities in $\mathrm{g} / \mathrm{cm}^{3}$.

Fig. 11 1-D velocity-depth profiles extracted from final RayInvr and Tomo2d velocity models below all OBSs, along Profile OBS2015-2. The dark grey area shows the range of typical velocities for the Atlantic oceanic crust (0-127 Ma) (White et al., 1992). The light grey area shows the area of SCS thinned continental crust based on many people's work (Nissen et al., 1995; Qiu et al., 2001; Yan et al., 2001; Wang et al., 2006). Blue lines with uncertainties indicate extended continental crust from Christensen and Mooney's work (1995).

Fig. 12 Comparison of inverted velocity models for Profiles T2, OBS2015-2 and T1. The upper boundary of slabs is deduced from the distribution of earthquakes. Models of Profiles T2 (a) and T1 
(c) are from Eakin et al. (2014).

Fig. 13 Tomography velocity structure and MCS image along Profile MGL0905_20 (Lester et al., 2014) located in Fig. 1. (a) Tomography velocity structure. Black arrows are intersections between Profiles T2, OBS2015-2, MGL0905_27 and T1 with Profile MGL0905_20. Red circles are OBSs locations, and grey mask indicates areas of poor ray coverage. (b) Interpretation of MCS reflection Profile MGL0905_20 (Lester et al., 2014). Distances (in km) correspond to distances on seismic refraction profile in (a). The green horizon indicates basement. Three regional unconformities (brown, yellow, and purple) may be mapped throughout the region, as well as the possible breakup unconformity (light blue). A weakly reflective lower crustal layer (dashed red horizon) is imaged below the distal margin, though residual multiples contaminate much of the deep crustal section (Lester et al., 2014).

Fig. 14 Comparison of unfolded Manila mid-slab tomographic velocities extracted from diverse $P$ and $S$-wave tomography models. (a) MITP08 global $P$-wave tomography (Li et al., 2008), (b) UUP07 global $P$-wave tomography (Amaru, 2007), (c) regional $P$-wave tomography (Koulakov, 2011), and (d) regional $S$-wave tomography (Koulakov, 2011). Black contours show the present Manila mid-slab depths in $\mathrm{km}$. The grey polygon masks tomographic velocities from the upper 75 to $100 \mathrm{~km}$, which are less reliable due to imposed crust correction within the tomography. As with all regional tomography models, (c) and (d) may contain velocity smearing artifacts at depth, meaning that velocities along the eastern most unfolded slab in (c) and (d) will be less reliable. Five velocity domains A to E generally occur within all four tomography models. We interpret slower areas A and E to be continental crust at the SCS conjugate margins, whereas fast areas B and D are the subducted SCS oceanic domains. Slow area C occurs outboard of the extinct SCS ridge and could be an SCS slab window (i.e., slab gap) or thermal anomaly from subducted young and warm SCS lithosphere. Slower velocity Feature $\mathrm{F}^{*}$ is located downdip of the thinned continental crust at the northeastern SCS shown in this study. ' $\mathrm{F}^{*}$ ' was not well-imaged across all tomography models and could possibly indicate a tomographic artifact or a rifted fragment within the Manila slab.

Fig. 15 Unfolded Eurasian-SCS (Manila) slab colored by its intraslab tomographic velocity $d V p(\mathrm{Wu}$ et al., 2016). The unfolded Manila slab is attached to the SCS along the Manila trench and extends 400-500 km east of the Manila trench. The N-S grey shadow mask ( $<100 \mathrm{~km}$ width) corresponds to imposed crust correction artifacts and was not interpreted. The SCS oceanic domain, characterized by $\mathrm{N} 055^{\circ}, \mathrm{N} 075^{\circ}$ and $\mathrm{N} 085^{\circ}$ seafloor spreading directions has been delimited by pink, yellow and light blue areas (Sibuet et al., 2016b), respectively. Major tectonic features are underlined. The extinct spreading ridge (ESR) in the East basin is from He et al. (2016) and Zhao et al. (2018b). The green line is the boundary of the typical oceanic domain (Sibuet et al., 2016b). Outside the continental shelves and the oceanic domain, the remaining parts of the SCS are thinned continental domain. The newly established COB4 (Fig. 1) appears as a red line called COB and has been extended in the unfolded Manila slab. The eastern extension of the ESR appears as a red thick dashed line. Locations of wide-angle seismic profiles T1, T2 and OBS2015-2 in black. Manila trench, black line with triangles; DF, Deformation front; TTZ, Taiwan transfer zone. 


\section{Highlights:}

1) Thinned continental crust intruded by post-rifting volcanics in northeastern SCS

2) The TTZ transfer zone separates two consecutive rifted continental segments

3) $\mathrm{COB}$ can be distinguished from $d V p$ variations within the unfolded Manila slab

4) Two plates kinematic arrangement at the end of SCS seafloor spreading 


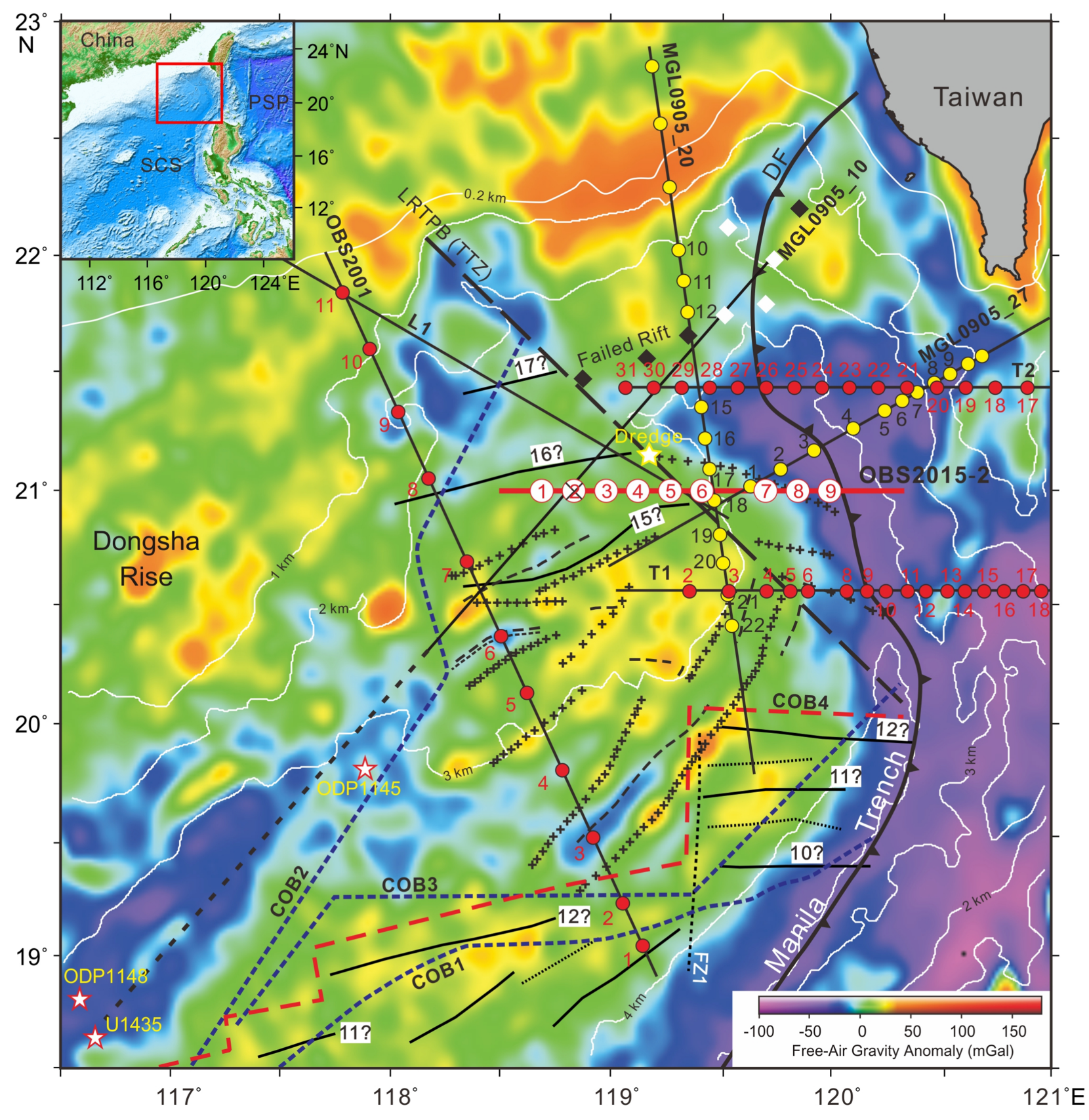

Figure 1 


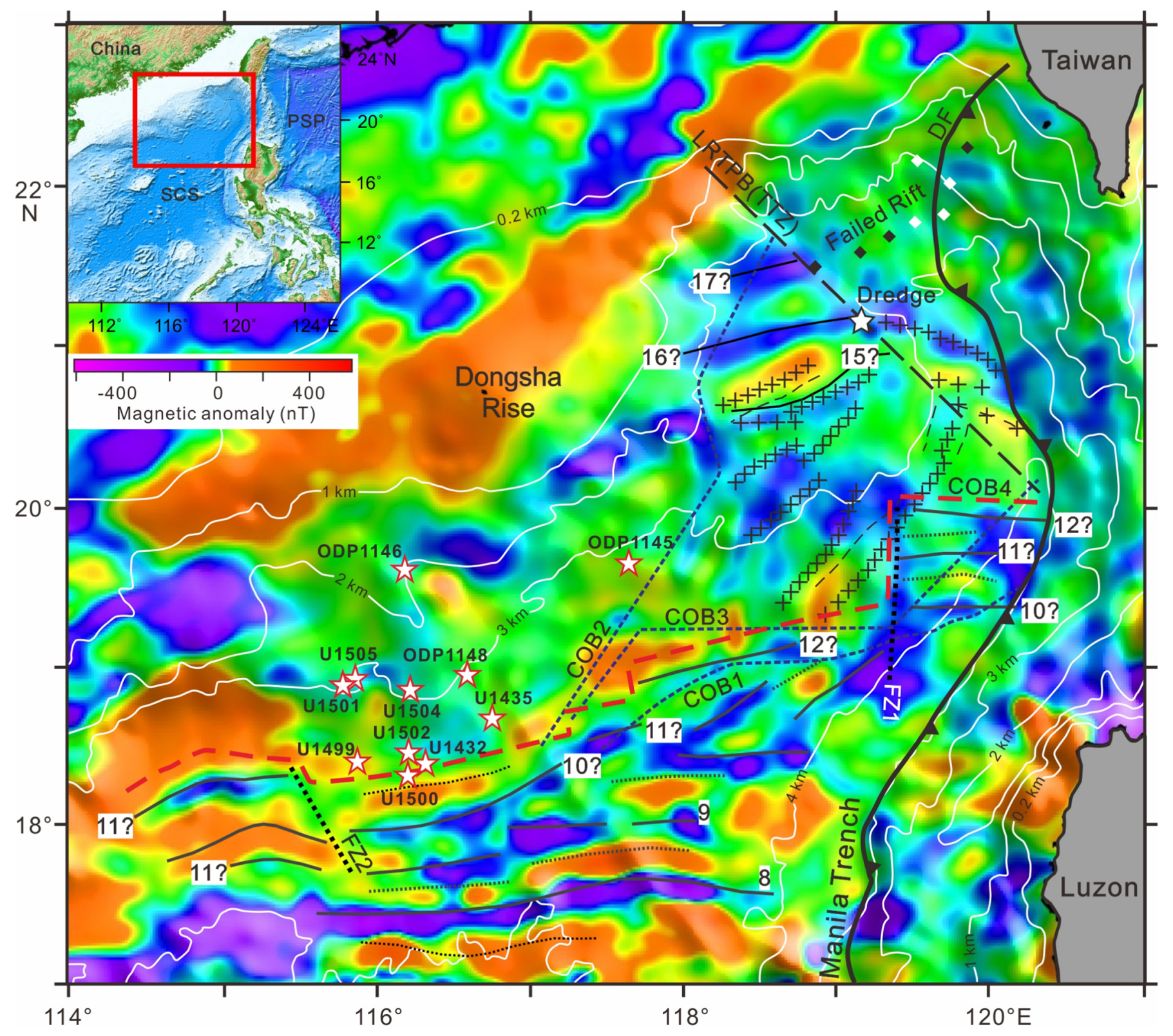

Figure 2 


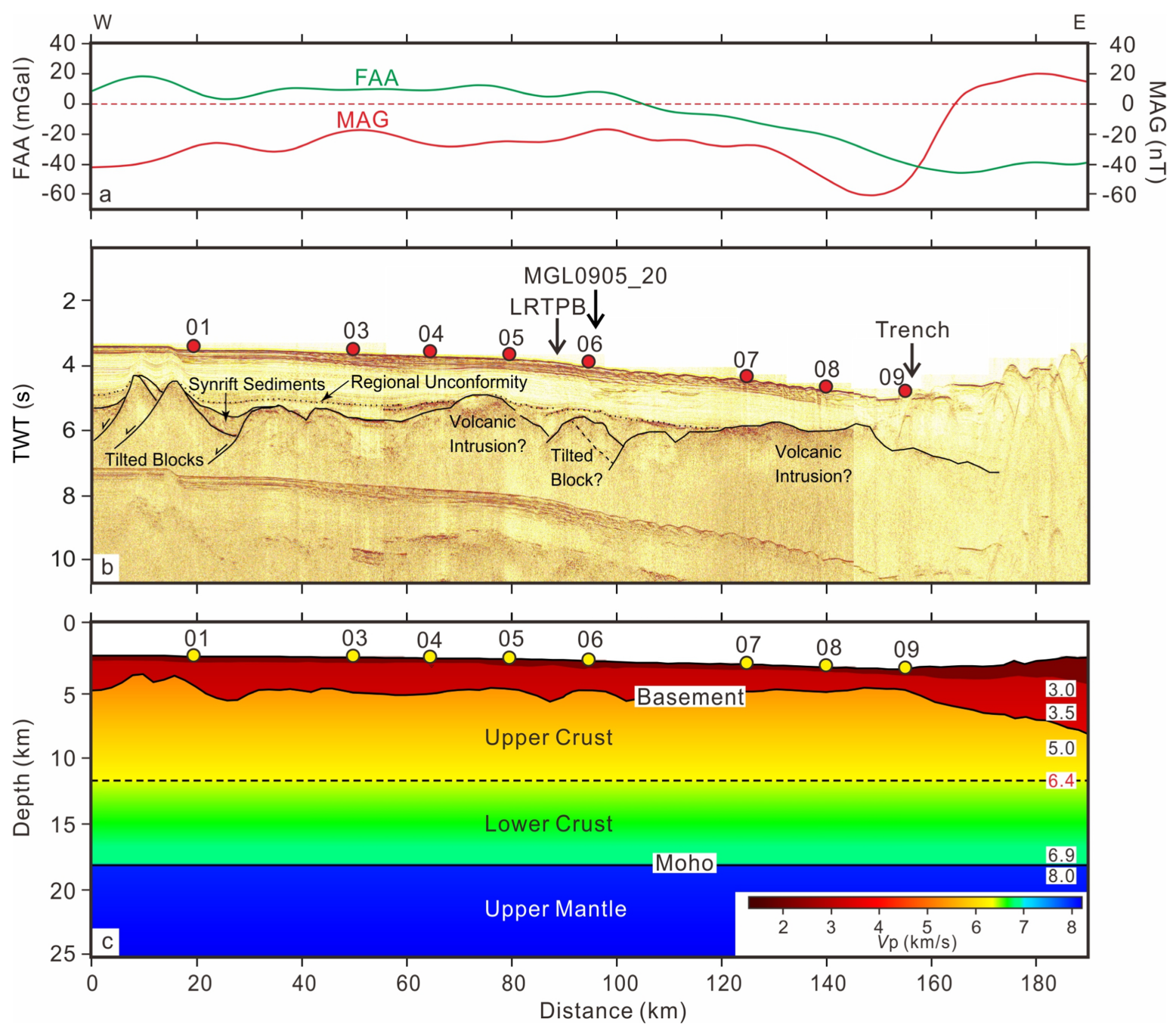

Figure 3 

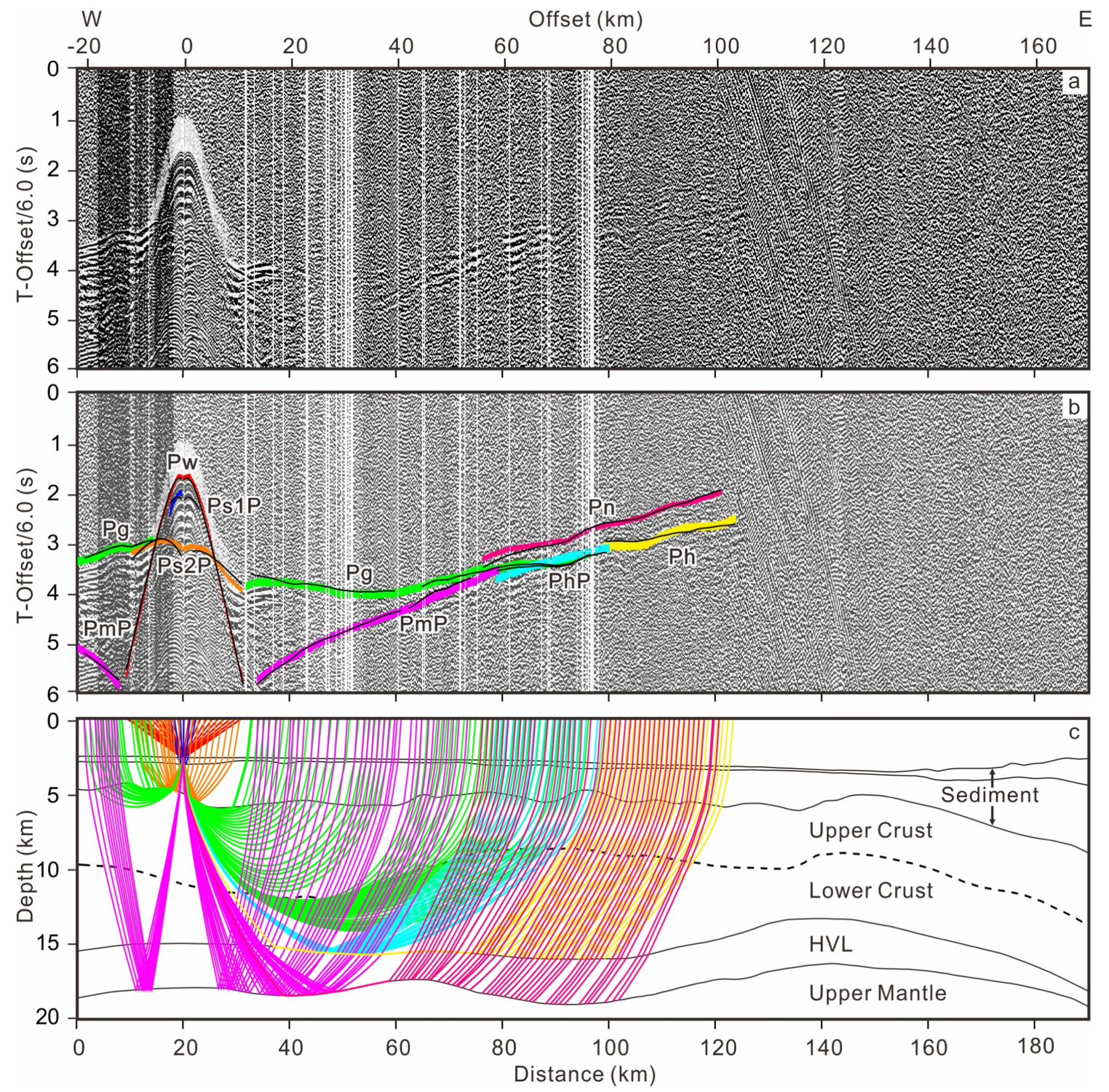

Figure 4 


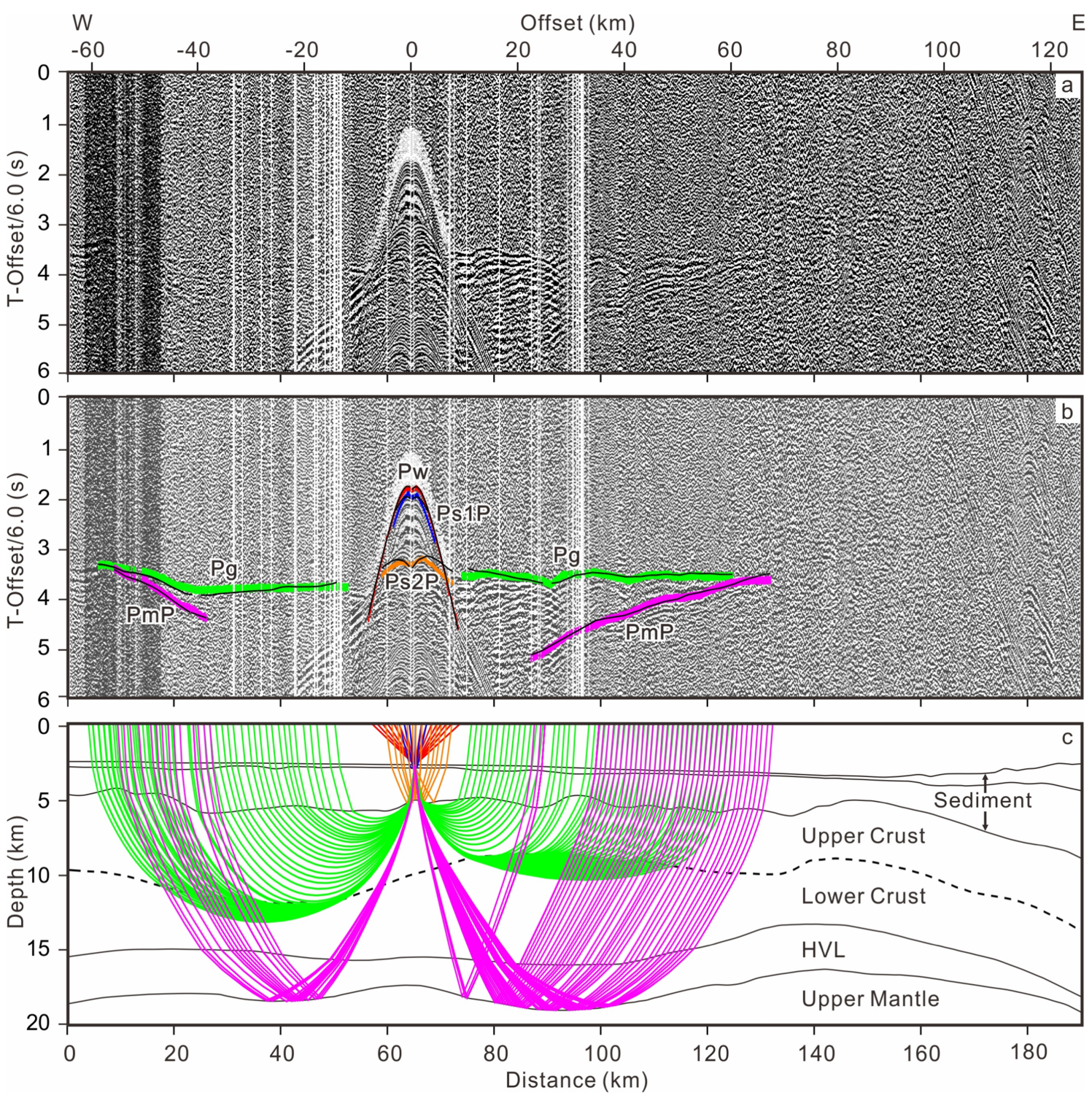

Figure 5 


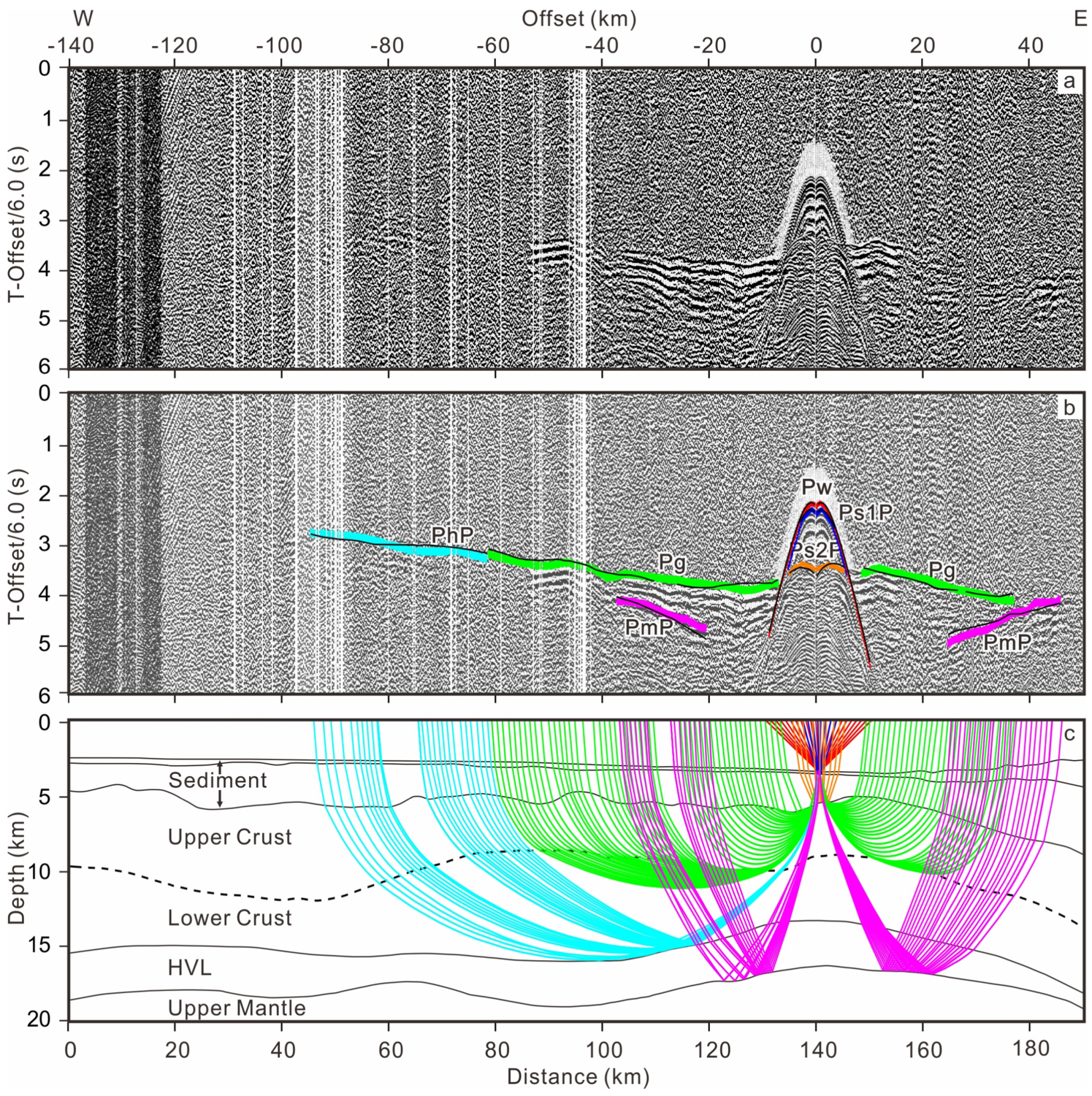

Figure 6 

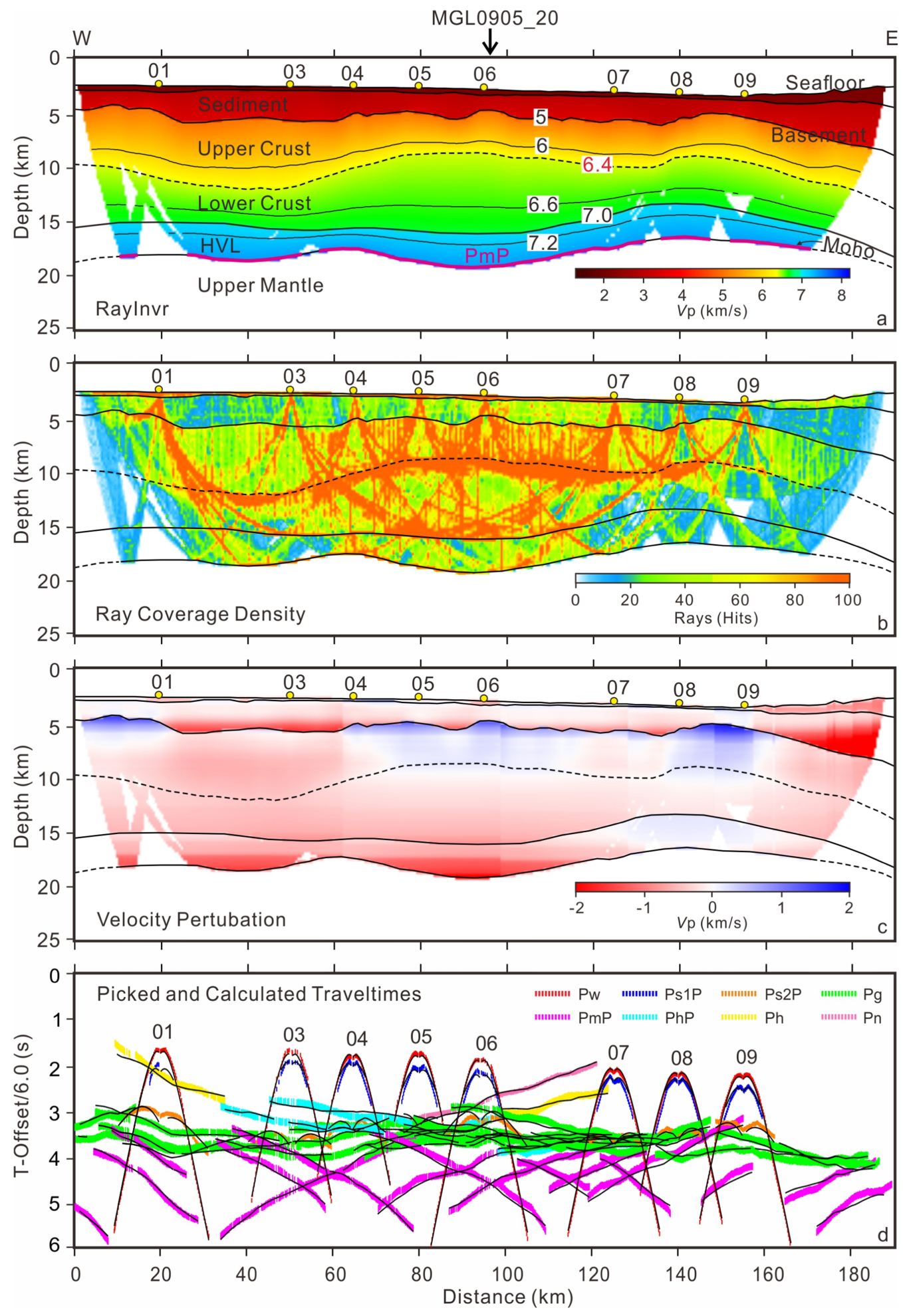

Figure 7 


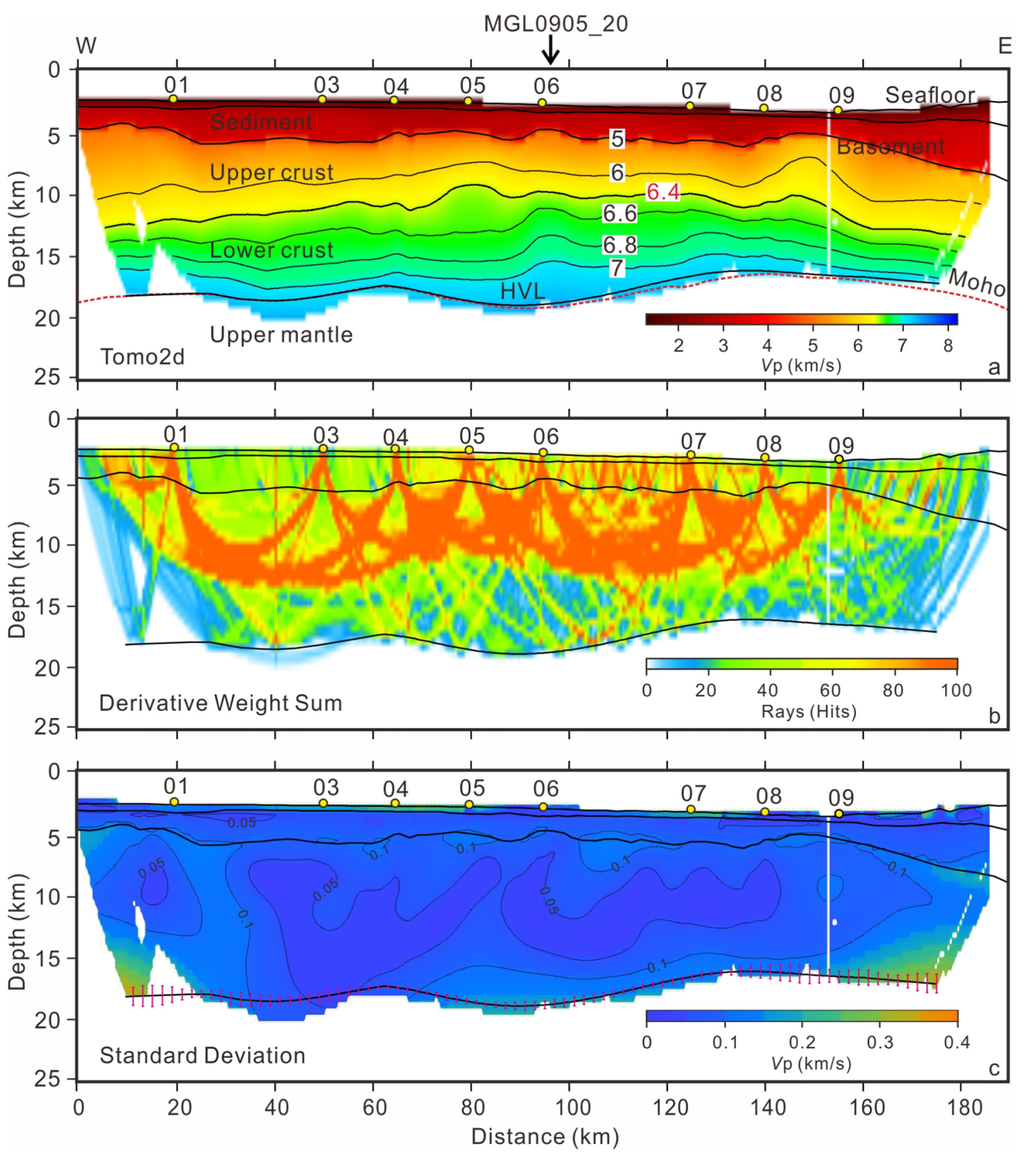

Figure 8 


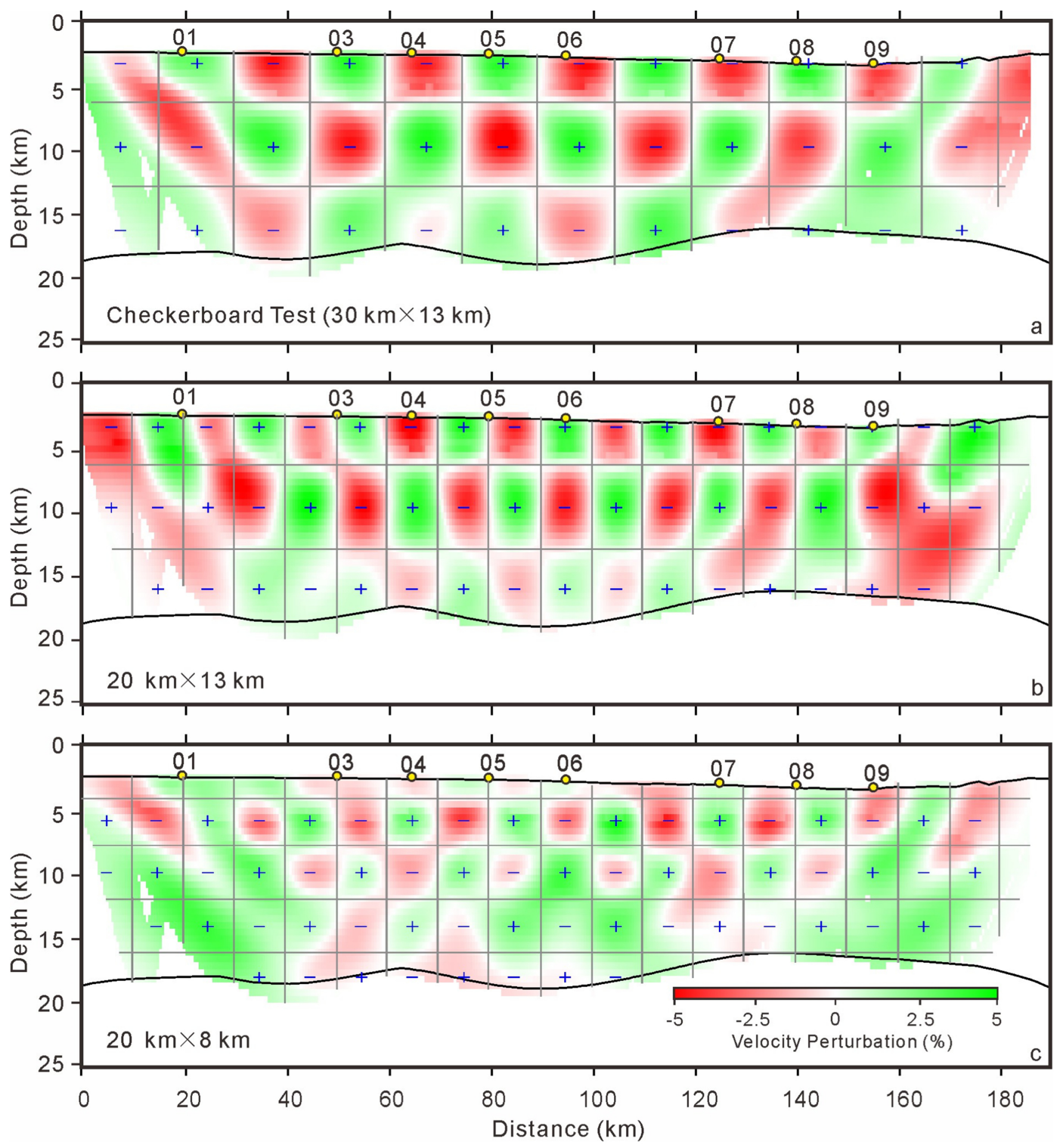

Figure 9 


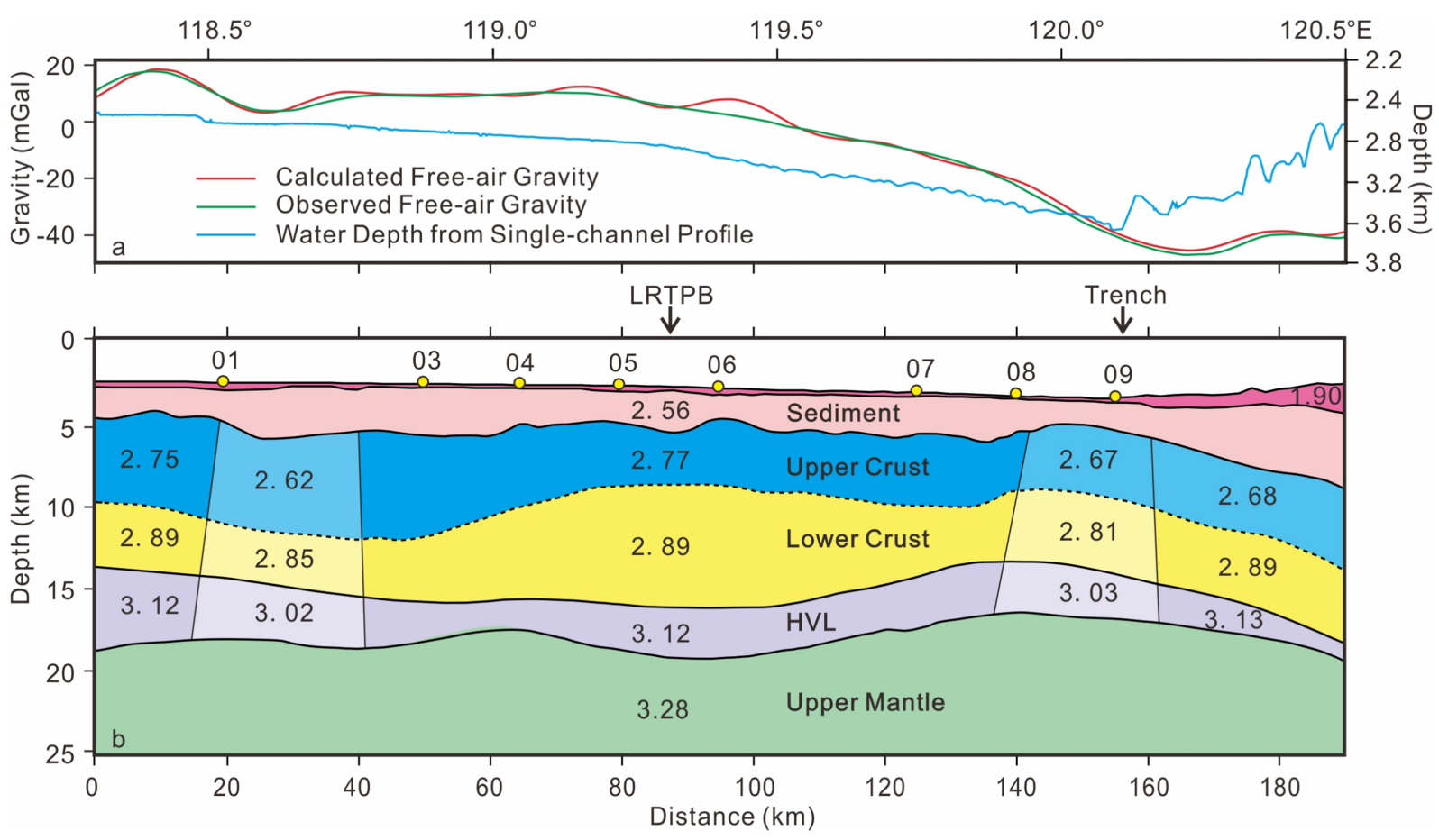

Figure 10 

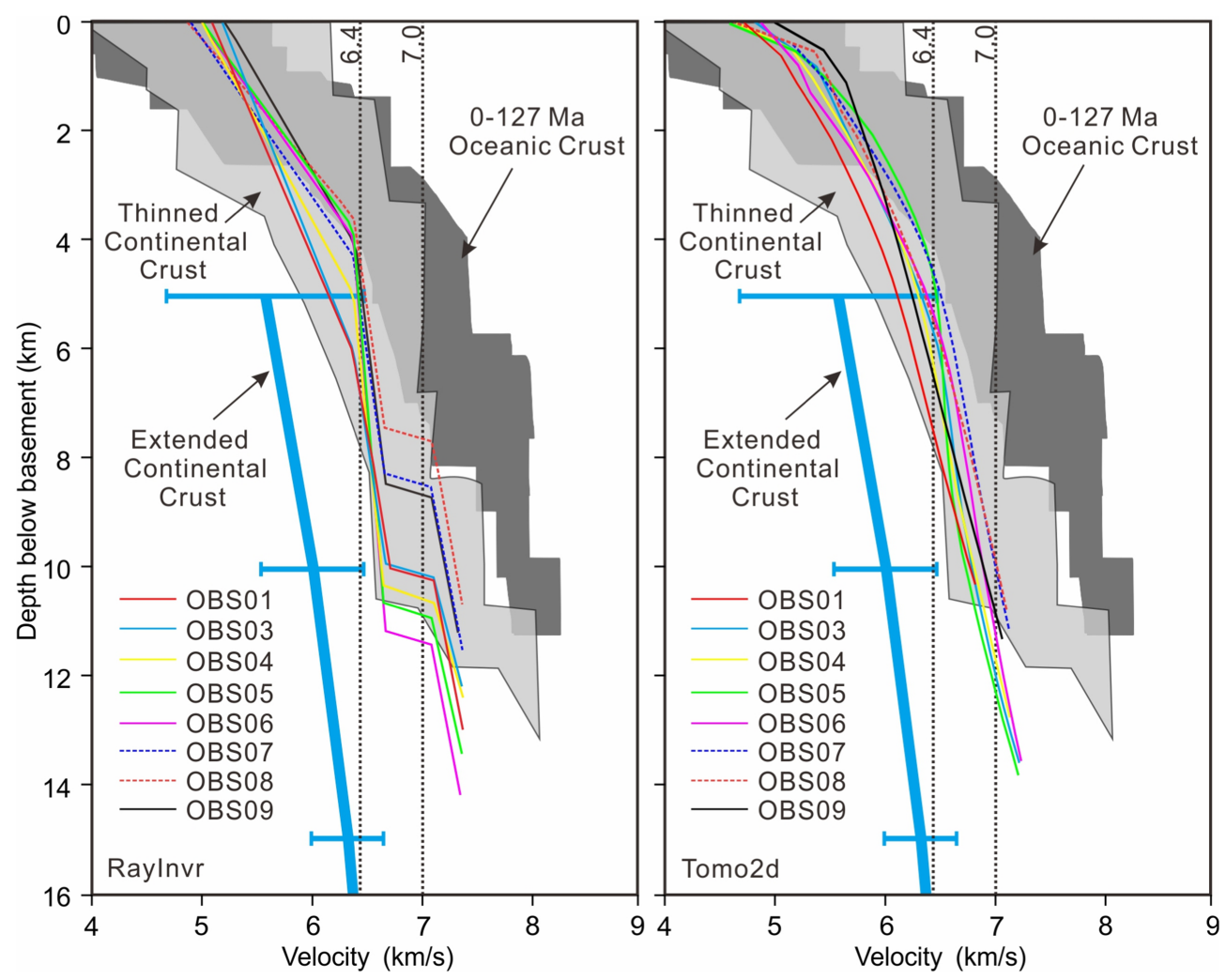

Figure 11 


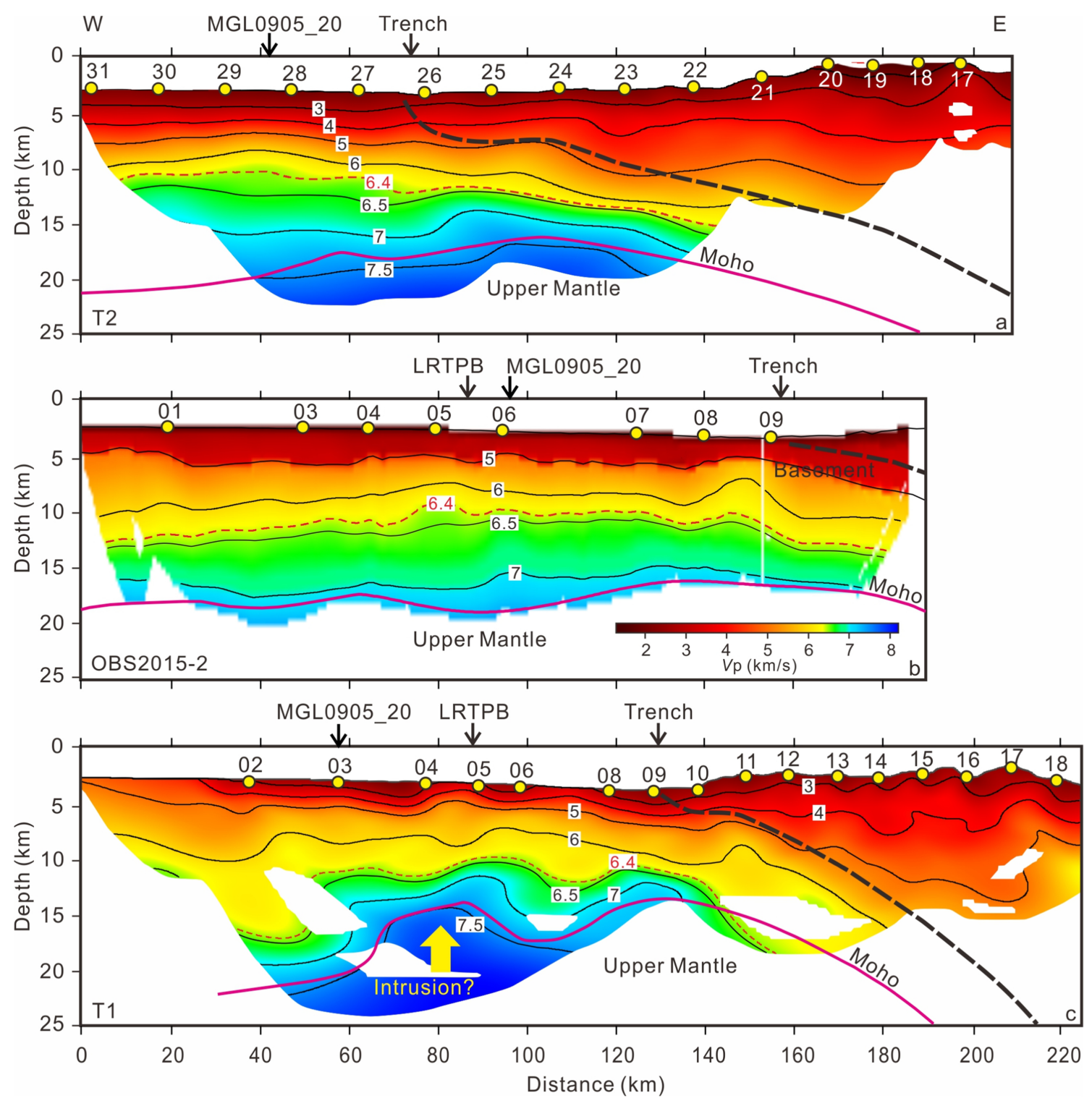

Figure 12 


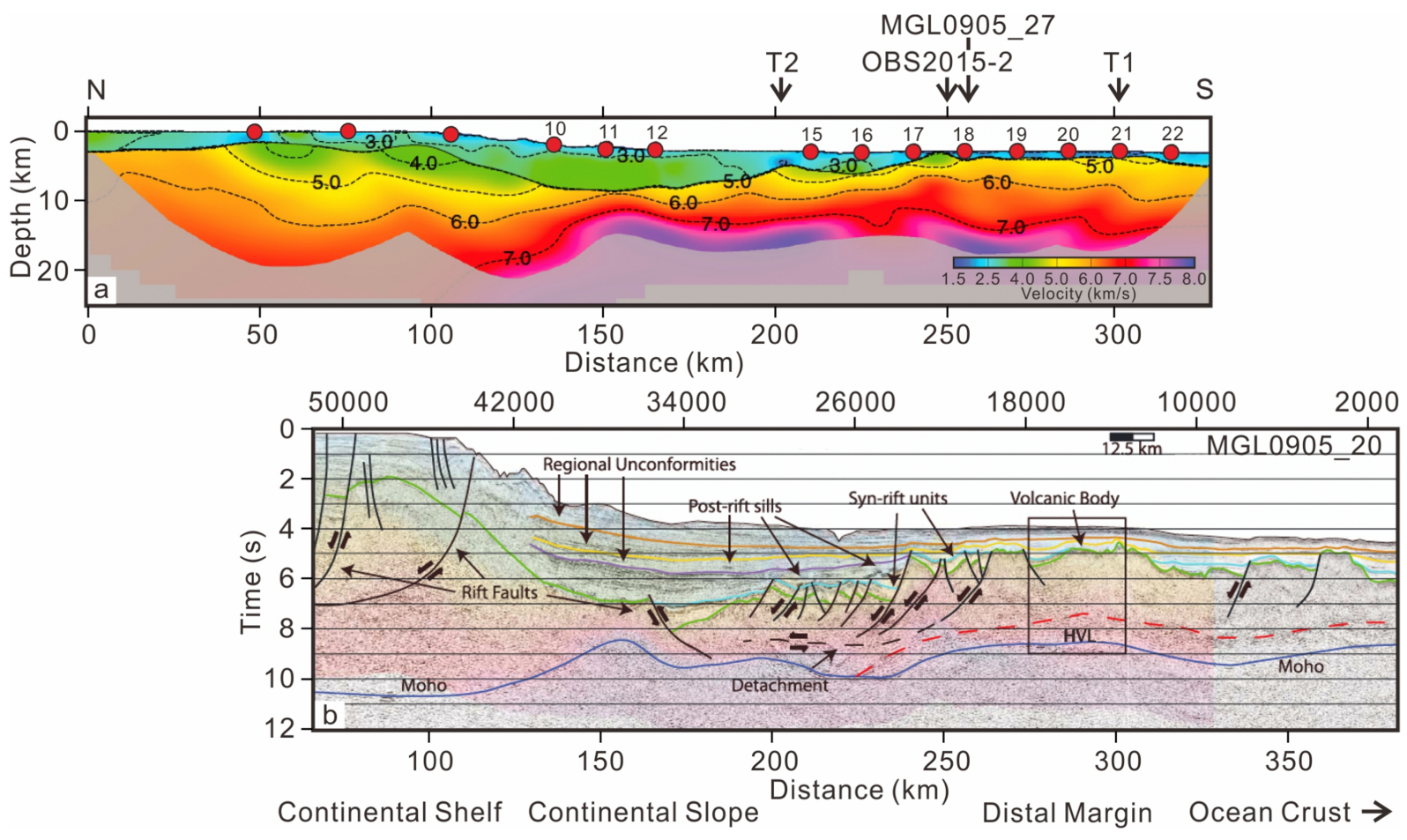

Figure 13 

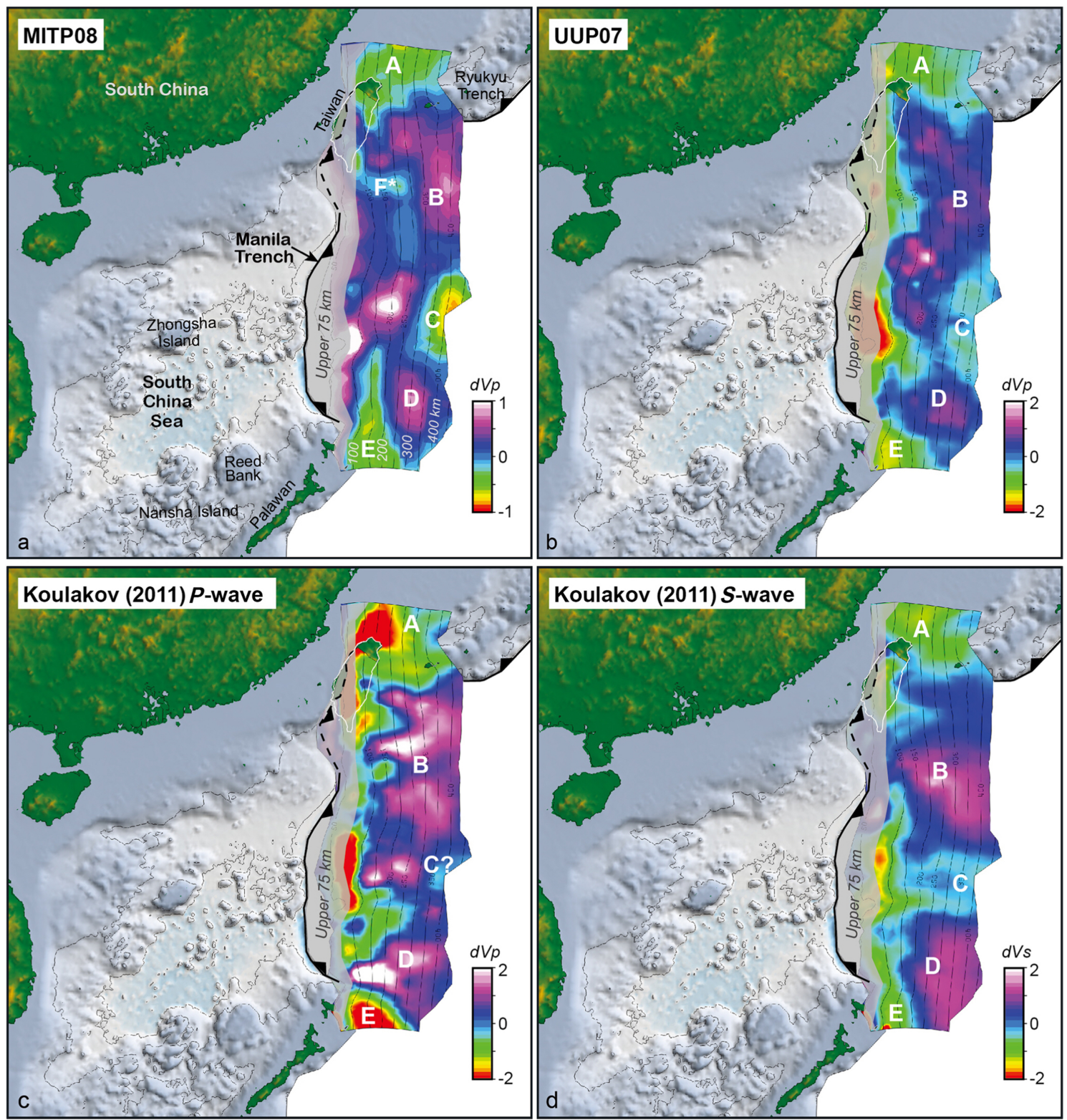

Figure 14 


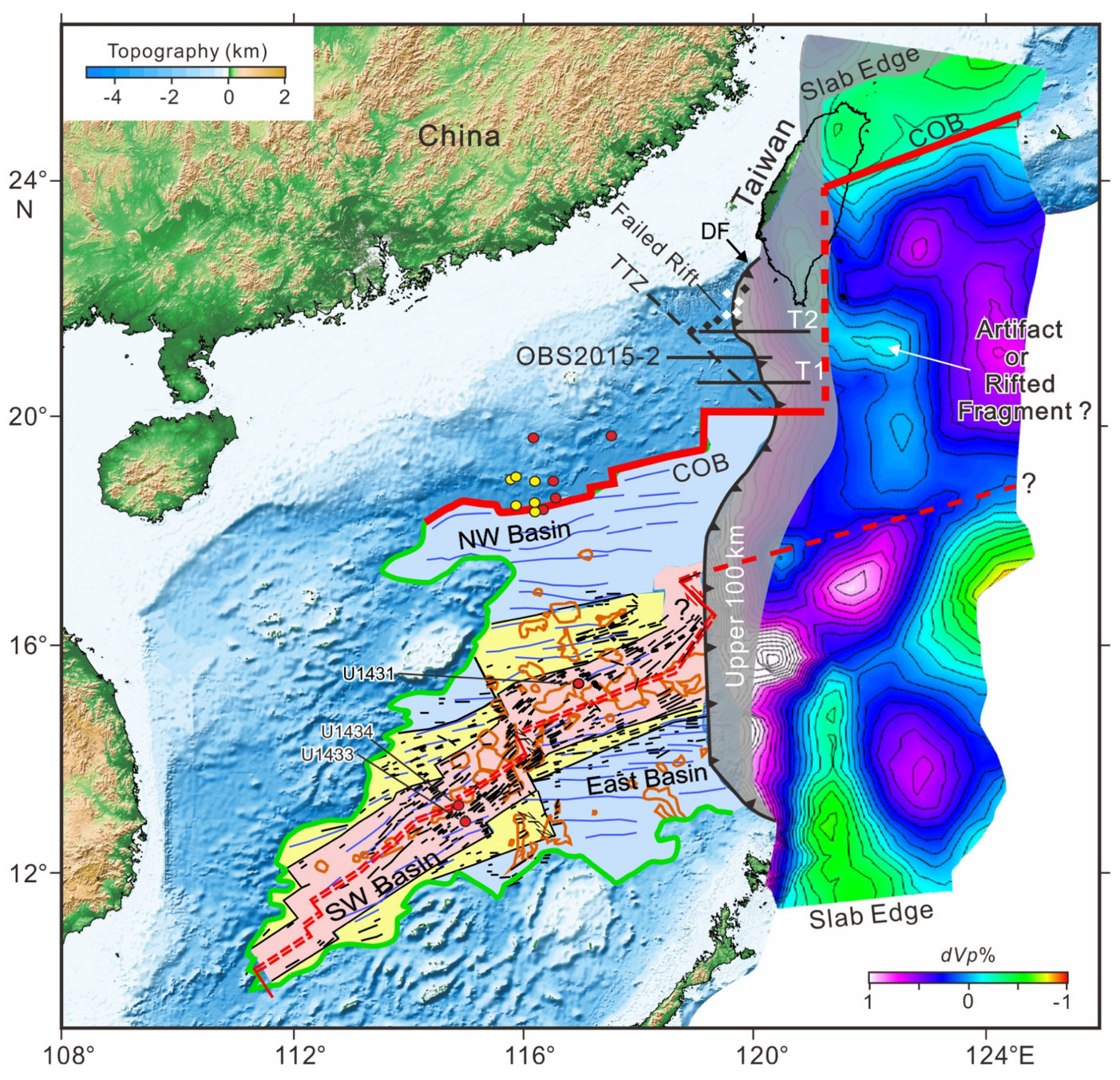

Figure 15 